\title{
Universal sexuality education in Mongolia: Educating today to protect tomorrow
}

Delia Barcelona

Laura Laski

Caitlin Gerdts

Follow this and additional works at: https://knowledgecommons.popcouncil.org/departments_sbsr-pgy

Part of the Family, Life Course, and Society Commons, Gender and Sexuality Commons, Gender Equity in Education Commons, and the International Public Health Commons How does access to this work benefit you? Let us know!

\section{Recommended Citation}

Barcelona, Delia, Laura Laski, and Caitlin Gerdts. 2002. "Universal sexuality education in Mongolia: Educating today to protect tomorrow," Quality/Calidad/Qualité no. 12. New York: Population Council. 
Universal Sexuality Education in Mongolia: Educating Today to Protect Tomorrow 



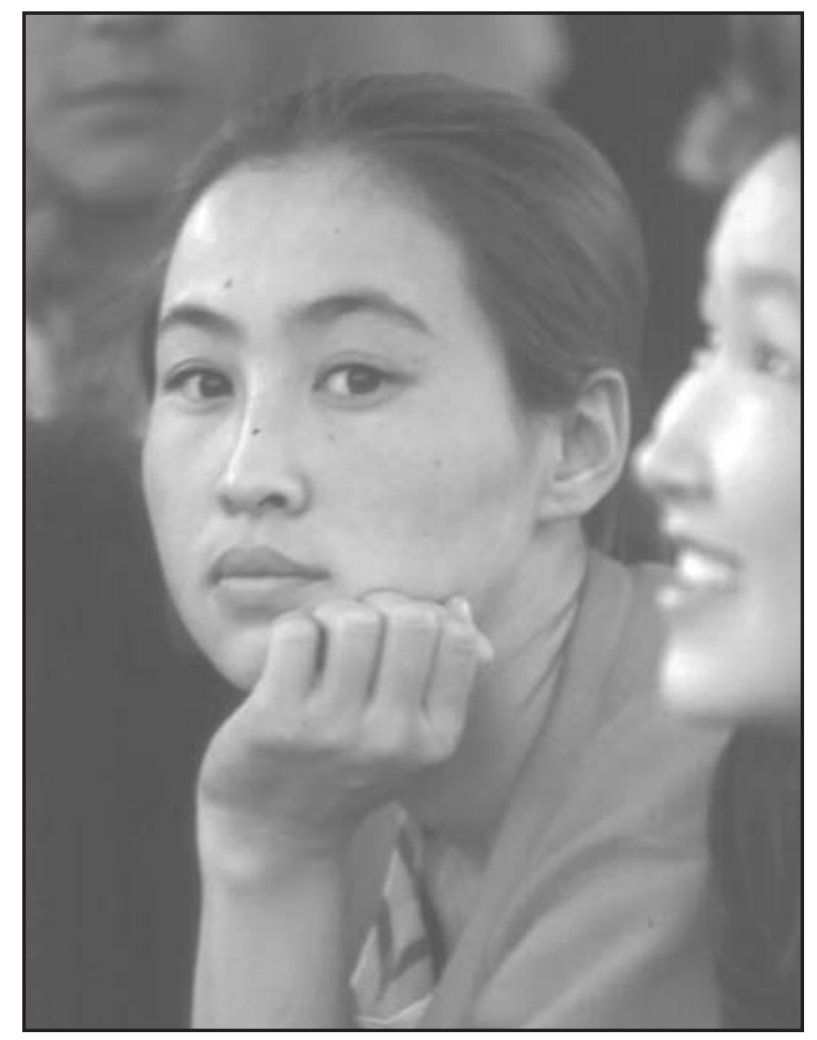

Universal Sexuality Education in Mongolia: Educating Today to Protect Tomorrow 
Quality/Calidad/Qualité, a publication of the Population Council, highlights examples of clinical and educational programs that bring a strong commitment, as well as innovative and thoughtful approaches, to the issue of high-quality care in sexual and reproductive health. The series is based on the philosophy that people have a fundamental right to respectful treatment, information, choice, and follow-up from reproductive health-care providers.

$Q / C / Q$ documents projects that are making important strides in one or more of the following ways: broadening the choice of methods and technologies available; providing the information clients need to make informed choices; enabling clients to become more effective guardians of their sexual and reproductive health; making innovative efforts to increase the management capacity and broaden the skills of service providers at all levels; combining health care, family planning, and related services in an innovative ways; and reaching underserved and disadvantaged groups.
Projects are selected for documentation by an advisory group made up of individuals who have a broad range of experience with promoting quality of care in sexual and reproductive health. None of the projects documented is being offered as a model for replication. Rather, each is presented as an unusually creative example of values, objectives, and implementation. These are learning experiences that demonstrate the self-critical attitude required to anticipate clients' needs and find affordable means to meet them. This reflective posture is exemplified by a willingness to respond to changes in clients' needs as well as to the broader social and economic transformations affecting societies. Documenting the critical choices these programs have made should help to reinforce, in practical terms, the belief that an individual's satisfaction with sexual and reproductive health services is strongly related to the achievement of broader health and population goals.

\section{(2) Population Council}

The Population Council is an international, nonprofit, nongovernmental institution that seeks to improve the well-being and reproductive health of current and future generations around the world and to help achieve a humane, equitable, and sustainable balance between people and resources. The Council conducts biomedical, social science, and public health research and helps build research capacities in developing countries. Established in 1952, the Council is governed by an international board of trustees. Its New York headquarters supports a global network of regional and country offices.

Population Council, One Dag Hammarskjold Plaza, New York, New York 10017 USA tel: (212) 339-0500, fax: (212) 755-6052, e-mail:qcq@ popcouncil.org, http://www.popcouncil.org.

Publication of this issue of Quality/Calidad/Qualité is made possible by support provided by the Ford Foundation, and by the Gender, Family, and Development Program of the Population Council. Statements made and views expressed in this publication are solely the responsibility of the authors and not of any organization providing support for $Q / C / Q$. Any part of this document may be reproduced without permission of the authors so long as it is not sold for profit.

Cover photograph courtesy of UNDP/Mongolia.

Number Twelve 2002 ISSN: 1097-8194

Copyright $(2002$ The Population Council, Inc. 


\title{
Introduction \\ What Are We Learning about Sexuality Education?
}

\author{
by Delia Barcelona and Laura Laski
}

There are now more than a billion young people between the ages of ten and 19 in the world (UNFPA 1999b). In their transition to adulthood, these young people face a range of challenges, the particularities of which are shaped fundamentally by their economic circumstances, gender, and culture. Along with services, life-skills training, and livelihood links, there is a universal need for sexuality and reproductive health education. How can the adults responsible for designing policies to protect adolescents' health and well-being best carry out this daunting charge?

The agreements made at the 1994 International Conference on Population and Development in Cairo and the 1995 UN Conference on Women in Beijing provide guidance. For example, the Cairo Programme of Action states that "Countries, with the support of the international community, should protect and promote the rights of adolescents to reproductive health education" and that "full attention should be given to the promotion of mutually respectful and equitable gender relations and particularly to meeting the educational and service needs of adolescents to enable them to deal in a positive and responsible way with their sexuality" (United Nations 1995).

Indeed, more countries are adopting reproductive health initiatives for adolescents, including both formal and informal sexuality education (UNFPA 1999b). Lending momentum to this trend is a growing body of literature documenting that sexuality education can contribute toward better health outcomes, including HIV prevention (Grunseit 1997; Kirby 2001). Additionally, most parents want their children to learn about the funda- mentals of sexuality, reproduction, and decisionmaking (MSCI 2000; KFF 2001; Esiet 2002). Finally, the reality of the HIV pandemic has given courage to some leaders in settings where they fear resistance to sexuality education programs and condom promotion.

Discussion is wide-ranging, however, about the most appropriate content, scope, and form of such programs. Although these will vary by setting, some findings are emerging from the literature.

The first is that abstinence-only approaches have not proved to be effective. No evidence has been found that such programs delay sexual intercourse (Kirby 2001; AFY 2002). Furthermore, by teaching adolescents to associate sexuality with fear and guilt, abstinenceonly curricula prepare them poorly for satisfying sexual lives as adults.

The second lesson is that, although specific circumstances vary by setting, a defining factor governing a teenager's autonomy, sexual health, and reproductive outcomes is gender. Because we are so accustomed to considering "adolescents" as a group distinct from adults, we often fail to see the defining differences between girls' versus boys' experiences and needs.

For girls, cultural, economic, and legal structures that foster submissiveness, limit schooling, constrain access to livelihoods, and encourage early marriage are among the influences on their ability to navigate their own sexual lives. For example, girls are frequently coerced into having unwanted sex in exchange for material favors or the hope of love, as an exercise in domination, or because they are forced into early marriages where they are sexually available to their hus- 
bands. Even in high-risk situations, girls are often unable to negotiate condom use; consequently, females account for 67 percent of new HIV infections among 15-24-year-olds in developing countries (UNICEF 2002). In addition, 40 percent of the 4.4 million girls who undergo abortion each year must do so in unsafe conditions (UNFPA 1999a).

Although girls are typically subject to the most grievous outcomes, boys suffer as well from current social arrangements. As a result of traditional masculine socialization, many boys suffer from internalized pressures to demonstrate their manhood in accordance with culturally accepted norms that may foster risk-taking and violence. Often, boys grow up profoundly confused by seeing their fathers hit their mothers, or by not having fathers around at all. Furthermore, the stigma attached to deviating from traditional (and heterosexual) male roles is often severe. The harmful effects of such pressures to boys' physical and mental well-being have been extensively documented (Barker 2002). Every day, boys are growing into men without the basic information or the opportunities to reflect that would enable them to become the kind of men they want to become, the fathers they would like to be.

Indeed, comparative studies on factors associated with early sex are a stark reminder that boys and girls occupy very different worlds. For example, a Mongolian study (MHSW and UNFPA 1996) cited in the following pages found that teenage boys tend to have intercourse for reasons of curiosity and pleasure, whereas girls say they do so for love. A US study found that among boys, high self-esteem in middle school is a predictor of early intercourse; conversely, high self-esteem among girls is a predictor for delayed sexual debut (Spencer et al. 2002). US-based research on the impact of athletic participation is similarly contradictory: Boys who participate in athletics are more likely to have early sex, whereas female athletes are less likely to do so (WSF 1998).

How is the approach to sexuality education evolving in response to our growing understanding about the underlying cultural factors that shape sexual behavior? Many sex educators have shifted from a strictly didactic approach to one emphasizing clarification of values, goalsetting, and communication skills. This modified approach often still lacks a gender analysis, however. By focusing on the generic adolescent or the adolescent "couple," such curricula, for the most part, have buried the critical issues. They have failed to take adequate account of boys' and girls' often distinct —and frequently competing - rationales, constraints, experiences, interests, expectations, feelings, and meaning in regard to sexuality and relationships.

Unfortunately, even when sexuality curricula have considered gender, typically the topic of gender is simply tacked on, often at the end of the curriculum. This happens for a variety of understandable reasons, including limited time for adding a topic and skepticism about the prospects of changing entrenched gender roles. A rapidly growing body of evidence, however, suggests that education programs can effect real change in the area of gender norms. Examples are available from around the world of small programs that are successfully enabling adolescent boys and girls to reflect on-and transcend-traditional gender roles as a way to improve the quality of their lives and reproductive health (CEDPA 2001; Barker 2002; Haberland and Measham 2002).

What might a sexuality and family-life curriculum that truly placed gender and power at its heart-that considered the meaning of "family life" in a fresh waylook like? Such approaches generally do not exist in school-based programs. Good curricula will, of course, provide students with basic information and help them to develop communication skills 
and self-respect. However, one more stretch is needed: Education can and should help young people become more cognizant of their social context and help them to analyze it critically. The architecture of such an approach, then, would be based on social studies. Both boys and girls would increase their knowledge and reflect upon such questions as the following (depending on local circumstances):

- What are the chances for school completion, income generation, and HIV transmission for girls versus boys in the country?

- Why do particular social or economic practices exist in the country, for example, the dowry system, early age at marriage for girls, female genital cutting, patterns of trading sex for money to pay school fees, and the habit of ignoring pervasive sexual violence?

- Who benefits from the current social structures? Who loses?

- Is there a better way to live?

Such a social studies framework could complement and give a meaningful foundation to subsequent technical sessions on puberty, contraception, prevention of sexually transmitted infections (STIs), sexual consent, self-esteem, and values, and political courage, driven by the willingness to overcome opposition in the name of the safety, well-being, and indeed, the survival of tomorrow's generation. In this issue of Quality/Calidad/Qualité, Caitlin Gerdts reports on P0 Zorgaa - the government of Mongolia's sexuality-education program, supported by UNFPA.

Like many postsocialist countries, Mongolia has an atypically high rate of female education, together with relatively low fertility. Nonetheless, it is facing many of the same challenges as the rest of the world in safeguarding the sexual and reproductive health of the next generation: rising STI rates, earlier ages of sexual debut, sexual violence, and a barrage of confusing and exploitative images and messages about sexuality in the media. The courageous example of the Mongolian government can encourage other countries that are considering how to implement this critical aspect of the Cairo and Beijing documents.

While P0 Zorgaa is not without its challenges and limitations, it is extraordinary in several key respects:

- The government made an explicit policy decision to support sexuality education for every Mongolian schoolchild every year, starting in third grade; placing these "health" topics in a larger context of development, equality, and human rights. Such an approach might lead, finally, not only to increased opportunities and postponement of marriage, but also to a delay in intercourse, more effective condom use, and reduced rates of disease and unwanted pregnancy.

In the meantime, it is important to give attention to country examples that are moving in a promising direction with intellectual
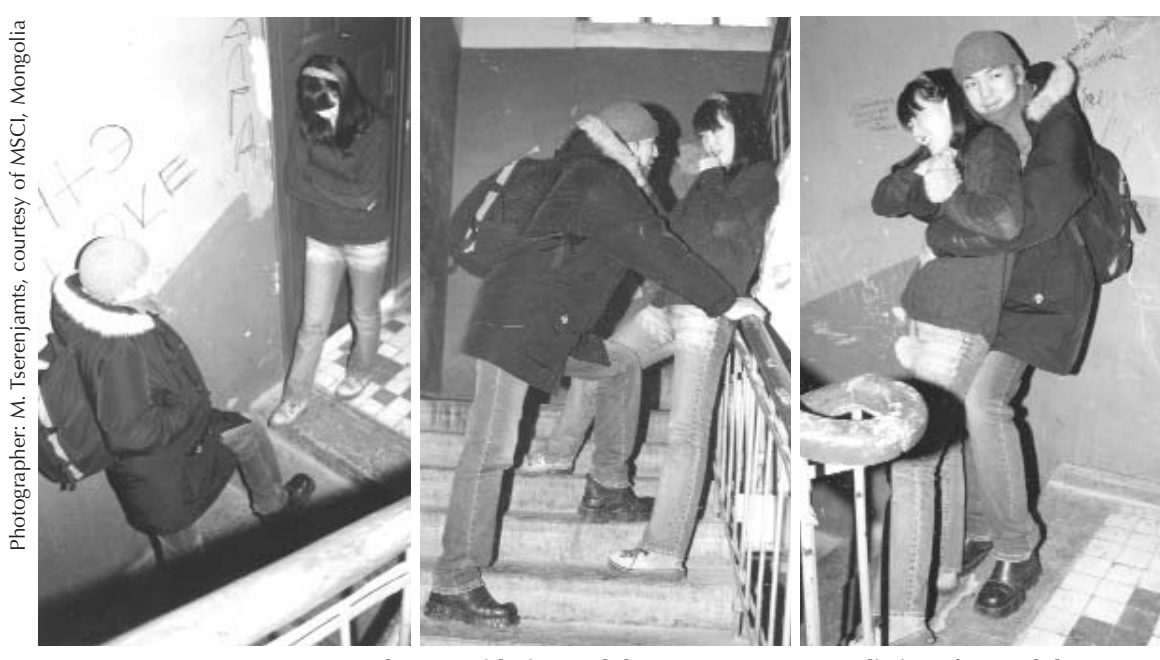

Because we are so accustomed to considering "adolescents" as a group distinct from adults, we often fail to see the defining differences between girls' versus boys' experiences and needs. 
- Rather than depend solely on outside experts to design the curriculum, the government invested in training a team of local experts who then developed and tested their own curriculum;

- The curriculum pays significant attention to the issue of gender.

Mongolian parents have been much more supportive of the program than many officials had feared might be the case. Of course, in some countries, conservative movements will oppose sexuality and family-life education vociferously when it deviates from the abstinenceonly approaches mentioned above. Without the courage of public health leaders, many young people in such settings will grow into adults who are not fully capable of having healthy sexual lives; others will not live to adulthood. We, too, need to ask ourselves: Who benefits from this? Who loses? Is there a better way to live?

\section{References}

Advocates for Youth. 2002. "Abstinence-onlyuntil marriage programs." <http://www.advocatesforyouth.org/abstinenceonly.htm >. Accessed 5/19//02.

Barker, Gary. 2002. "Engaging adolescent boys and young men in promoting sexual and reproductive health: Lessons, research, and programmatic challenges," in background document prepared by the Population Council for the UNFPA Workshop on Adolescent and Youth Sexual and Reproductive Health: Charting Directions for a Second Generation of Programming. New York: Population Council.

Center for Development and Population Activities (CEDPA). 2001. "Adolescent girls in India choose a better future: An impact assessment." <http://www.cedpa.org/publications/ pdf/blp_report.pdf $>$. Accessed 5/24/02 .

Esiet, Adenike. 2002. "Building support for adolescent health education and services in Nigeria: Reflections from the experience of Action Health Incorporated," paper presented at the UNFPA, WHO, and The World Bank panel on Adolescents at the Crossroads: Learning about Health and Rights. New York, 8 May.
Grunseit, Anne. 1997. "Impact of HIV and sexual health education on the sexual behaviour of young people: A review update." UNAIDS. <http://www.unaids.org/ publications/documents/children/schools/ grunskme.pdf>. Accessed 5/22/02.

Haberland, Nicole and Diana Measham, eds. 2002. Responding to Cairo: Case Studies of Changing Practice in Reproductive Health and Family Planning. New York: Population Council.

Henry J. Kaiser Family Foundation (KFF). 2001. "The AIDS epidemic at 20 years: The view from America. A national survey of Americans on HIV/AIDS." <http://www.kff.org/content/2001/3183>. Accessed 5/22/02.

Kirby, Douglas. 2001 Emerging Answers: Research Findings on Programs to Reduce Teen Pregnancy. Washington, DC: National Campaign to Prevent Teen Pregnancy.

Margaret Sanger Center International (MSCI). 2000. "Results of focus group discussions on adolescents' knowledge, practice, related to sexuality, attitudes, and their service needs." Unpublished program document. Ulan Bator: MSCI.

Mongolian Ministry of Health and Social Welfare (MHSW) and UNFPA. 1996. Adolescent Reproductive Health Survey. Ulan Bator: MHSW.

Spencer, Jennifer M. et al. 2002. "Self-esteem as a predictor of initiation of coitus in early adolescents." Pediatrics 109(4): 581-584.

United Nations. 1995. "Programme of Action of the International Conference on Population and Development, Cairo, Egypt, 5-13 September 1994," in Report of the International Conference on Population and Development, UNDoc.A/CONF.171.13/Rev.1. Paragraphs 7.3, 7.46. New York: United Nations.

UNFPA. 1999a. Annual Report. <http://www. unfpa.org/about/report/report99/report99e ng.pdf>. Accessed 5/24/02.

UNFPA. 1999b. The State of the World Population 1999. Chapter 3: "Reproductive Health and Reproductive Rights." <http://www. unfpa.org/swp/1999/chapter3d.htm>. Accessed 5/14/02.

UNICEF. 2002. "Girls and HIV/AIDS." <http:// www.unicef.org/programme/lifeskills/priorities/girls_hiv.html>. Accessed 5/14/02.

Women's Sports Foundation (WSF). 1998. "The Women's Sports Foundation Report: Sport and Teen Pregnancy." East Meadow NY: WSF. 


\title{
Universal Sexuality Education in Mongolia: Educating Today to Protect Tomorrow
}

\author{
by Caitlin Gerdts
}

\section{Modern Mongolia}

Mongolia is a vast expanse of steppe, desert, and mountains landlocked between Russia and China where temperatures during the long winter hover as low as $-30^{\circ} \mathrm{C}$. Close to 2.4 million people call this country home, with a third of the population living in the capital and only major city, Ulan Bator. ${ }^{1}$

Despite, or perhaps because of, centuries of foreign occupation, Mongolsof whom 82 percent are ethnic Khalkh (NSO and UNFPA 2001) — have a strong sense of identity and take pride in their country and in maintaining their traditional culture. For example, even today, Mongols generally use only one name; when bureaucratic or formal occasions require more precise identification, they add their father's or mother's first initial or name as a sort of identifier. Traditional music and dress are still common in the city as well as the countryside.

The country was ruled by the Chinese for most of the eighteenth, nineteenth, and early twentieth centuries. In 1917, during the Russian Revolution, Mongolia became a battleground for conflicts among the Chinese, White Russians, and Bolsheviks. The Mongols eventually threw in their lot with the Bolsheviks, establishing the People's Government of Mongolia, nominally headed by a traditional Buddhist leader. In the late 1920s, however, communists replaced the religious leader, and Mongolia became a satellite state of the USSR, falling almost completely under Soviet political control. For most of the past century, the government was socialist.

Socialist rule produced a planned economy, proscriptions against religion, investments in basic services such as health care and education, and the

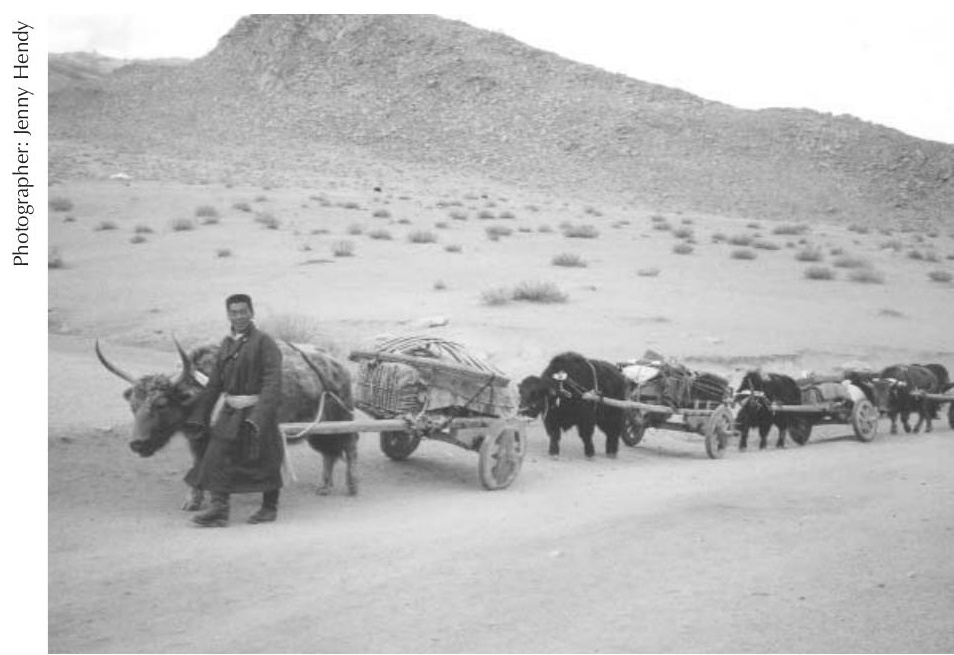

Although urban areas attract a constant flow of migrants, close to half the population still earns its livelihood by farming and herding. The nomadic herders take down and rebuild their circular dwellings, or ger, as they move their livestock across the grassy steppe.

promotion of gender equity in many spheres. Collectivization of farming eased the need for child labor, and the Mongolian government not only provided universal education but also required all families to send their children to school through the eighth grade. 


\section{Democracy and the Rights of Women}

Mongolia's constitution, drafted just over a decade ago, guarantees the rights to free speech, religion, and assembly, as well as multiparty elections. It also prohibits discrimination on the basis of sex and guarantees that "men and women shall enjoy equal rights in political, economic, social, cultural fields, and in marriage" (Constitution of Mongolia, cited in Sabloff 2001). Indeed, the punishment for obstructing a woman from exercising these rights is a fine of up to 100,000 tg (about US\$90) or three years' imprisonment (Patel and Amarsanaa 2000). The constitution further states that "Marriage shall be based on the equality and mutual consent of the spouses who have reached the age determined by law," currently set at age 18 .

The dismantling of the collective farm has had an impact on education and gender roles. Once again, families need their sons to help with herding. A strong cultural pride is attached to boys' ability to survive and take care of themselves through their physical labor, so that now many boys leave school by early adolescence. On the other hand, girls are seen as relatively expendable from an economy and daily life organized around herding; they are considered as more in need of an education than boys in order to become productive and selfsufficient. Moreover, girls tend to perform better academically, and therefore, they advance to the university level in greater numbers than boys. As a result, since 1990 Mongolia has had an unusual gender disparity in terms of education. Whereas primary-school classrooms have an almost equal number of girls and boys, among 15-19-year-olds, girls comprise 57 percent of the student body. This discrepancy increases with years of schooling, so that young women make up 60 percent of college graduates each year (NSO and UNFPA 2001; Lhagvasuren 2002). As a result, in many marriages, the woman is the more educated partner (NSO and UNFPA 2002).

Not surprisingly, urban women still fill the ranks of the professional classes: Four out of five doctors and more than three of five lawyers are female. The tendency remains for top positions to be occupied by men, however. Although 93 percent of primary-school teachers and 70 percent of secondary-school teachers are female, only 23 percent of school principals are women. (Ministry of Health and Social Welfare [MHSW] and UNICEF 2000). Furthermore, 91 percent of the members of parliament (Lhagvasuren 2002) are male.

Universal health care has been sustained, with a shift toward preventive care. This shift, along with the expanded space for political and cultural debate, has influenced sexual and reproductive health policy. On one hand, the government has maintained childbearing incen-

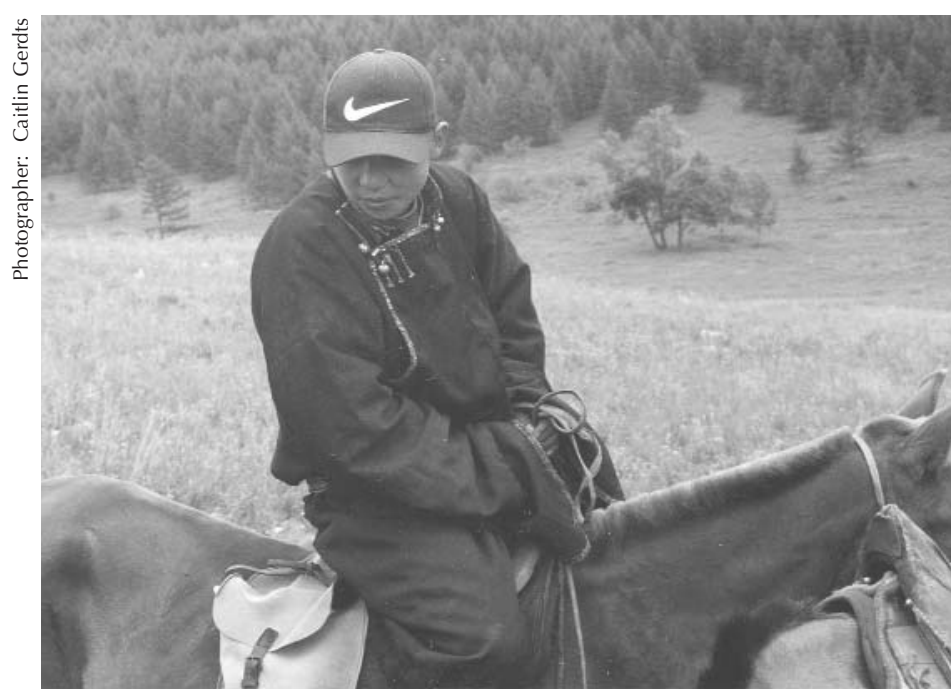

Because a strong cultural pride is attached to boys' ability to survive and take care of themselves through their physical labor, many boys now leave school by early adolescence. As a result, girls predominate in secondary school and university. 
tives, that is, large families still receive social welfare benefits. Concomitantly, the state has recognized the individual's right to make decisions about childbearing. In the last decade, as a public health measure, the government began wide provision of contraceptive information and services. In 1998, 44 percent of all women aged 15-49 were using a contraceptive, and 33 percent were using a modern method (NSO and UNFPA 1999).

First-trimester abortion was legalized in 1989. Purevsuren, a prominent obstetrician-gynecologist, explained the straightforward rationale for legalizing the procedure:

There was a high rate of nonmedical (untrained) people performing abortions using all kinds of methods. There was a lot of sepsis and trauma-and it was costing a lot of money to treat. A group of doctors asked that it be legalized, and so it was.

Although women in remote rural areas still have difficulty obtaining an abortion and contraceptive services (particularly in winter, when travel is a great obstacle), the days when typical family size was in the double digits are long gone. Today, the typical Mongolian family has three children.

\section{Changes in Sexual}

Experience, Marriage

Patterns, and the

Reproductive Health of

\section{Adolescents}

The new Mongolia, having opened its borders in 1990, understandably confronts modern dilemmas. On one hand, increased freedom of movement has allowed for travel to and from foreign countries, and Mongolians now have far greater opportunities for business, tourism, and study. Of course, the borders

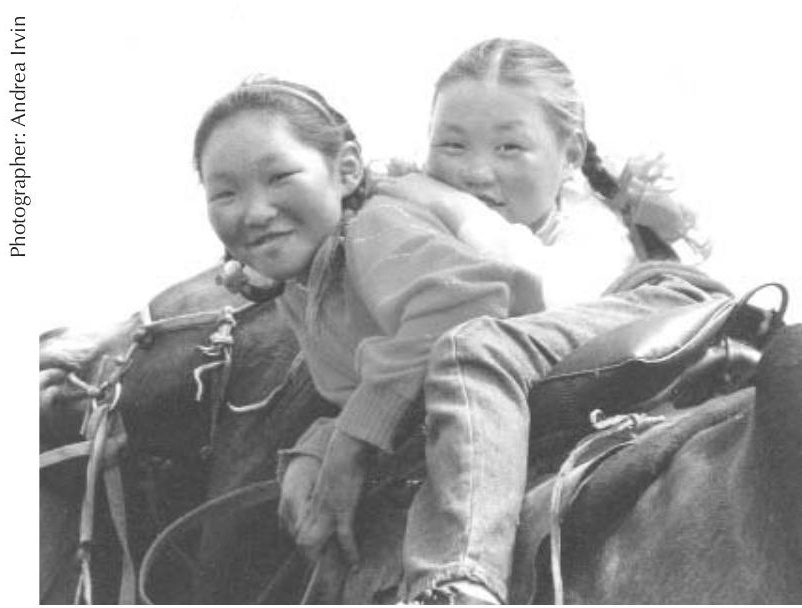

After opening its borders in 1990, Mongolian society was flooded with popular media from other countries. As young Mongolians encountered new representations of romance and sexuality, social norms began changing.

were opened not only to individuals but also to the vehicles of culture, including the suddenly ubiquitous popular media of foreign countries, particularly Europe and the United States. Before 1990, the only films available were Russian or Mongolian movies in which scenes of a sexual nature had been cut; even a film kiss was considered risqué. Now tastes in popular music and fashion have begun to mimic the films and television shows (for example, MTV) from the West. Furthermore, as press constraints were relaxed, many tabloid newspapers began to publish erotic photos on the front pages.

Media representations of romance and sexuality have contributed to changing social norms. Whereas public displays of affection did not exist before 1990, now, although kissing in public remains taboo, couples commonly walk hand in hand. Young people's views concerning sexual intercourse appear to be changing as well. Oyun, a 35year-old female physician, comments on this culture shift:

When I was a teen, a boy would meet his girlfriend after school and carry her backpack, take her to a movie, help with some household things. (Sexually,) the most exciting thing to hear was that someone kissed someone. 
It changed rapidly with the transformation of the system. I can't really point to the time when it happened, but in 1994 or '95, I realized that having a girlfriend or boyfriend meant to have sex, at least for college and some high-school students. I believe the influence of free mass media played a huge role in this transition.

A girl is no longer expected to be a virgin at marriage; indeed, the age of sexual initiation appears to be decreasing. In 1995, an adolescent reproductive health survey found that 26 percent of teenagers aged 17-18 had had sex; by 1999, this figure had risen to 35 percent (MHSW and UNFPA 1996; Reilley et al. 1999). Sex-disaggregated data from the 1995 survey show a marked gender gap: 36.3 percent of boys aged 17-18 reported having had intercourse, compared with 18.8 percent of girls. When asked their reasons for first having sex, the most frequent response among girls (44 percent) was "to show love," while 56 percent of boys offered "curiosity and pleasure" as motives.

Along with earlier onset of sexual activity, both men and women are marrying later. Between 1989 and 2000, the mean age at first marriage for women increased from 21.1 to 23.7 years; the mean age for men rose from 23.3 to 25.7 years (NSO and UNFPA 2001). Data on marriage and on premarital behavior, however, are difficult to interpret; younger couples commonly live in informal unions (called "sitting togeth$\left.\mathrm{er}^{\prime \prime}\right)$, referring to each other as "husband" and "wife," but not registering their marriage with the state until after the arrival of a first birth. This attitude toward legalized union was expressed by one young man who proudly announced that his wife was going to have a baby. Asked if he was going to marry her formally, he responded, "We'll do it sometime. It isn't important to us." Regardless of whether they eventually settle into formal or informal unions, most girls remain with their families throughout adolescence; in 2000, only 6 percent of females aged 15-19 were married or cohabiting (NSO and UNFPA 2001).

Despite the rising rates of contraception among adult women, adolescents are generally at high risk of both unwanted pregnancy and sexually transmitted infection. A survey of teenagers between the ages of 11 and 18 who have had intercourse found that only 36 percent used any form of contraception the first time they had sex (Irvin forthcoming). Indeed, since 1990, Mongolia has witnessed a significant rise in the rate of STIs and unwanted pregnancies among teenage girls, whose contribution to the total number of abortions more than doubled between 1996 and 2001 (National Center for Health Development [NCHD] and UNFPA 2001). Between 48 and 52 percent of sexually transmitted infections

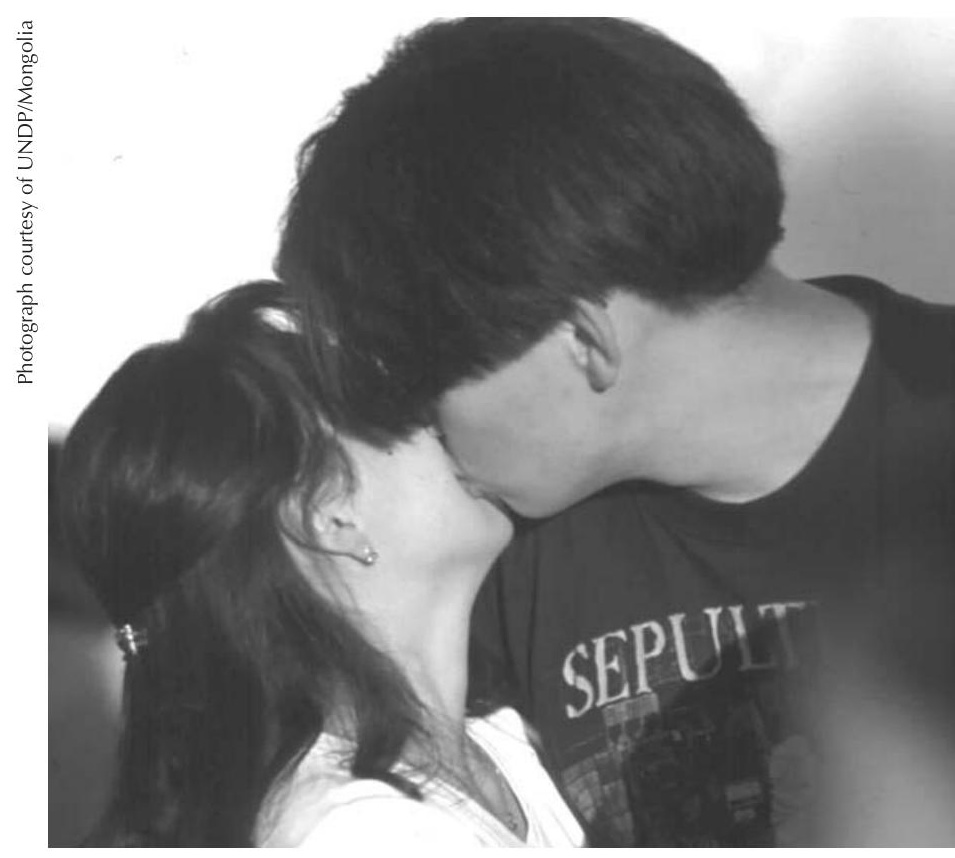

As is true in many settings, the primary reasons for first having intercourse differ by gender: Girls most frequently want "to show their love," whereas the majority of boys say "curiosity and pleasure" are their main motives. 
now occur among young people younger than 25 (Purevdawa et al. 1997; MHSW 1998). Although adolescents comprise about 25 percent of the population (NSO 2001), clinical services, for the most part, are either unavailable or unappealing to teens. Moreover, the adolescent survey cited above (Irvin forthcoming) documents that adolescents' main source of information about reproductive health and sexuality is friends, with television and newspapers being secondary sources.

\section{The Government Responds to Changing Needs of Adolescents}

In 1997, the Ministry of Health and the Ministry of Enlightenment (recently renamed the Ministry of Science, Technology, Education and Culture-or MOSTEC) established a joint initiative to promote the country's new commitment to a preventive approach to public health

\section{Ministry officials asked themselves what adolescents needed to know if they were going to reduce their risk of unwanted pregnancy, STIs, and physical abuse. As one official recalled, "We didn't have a clue."}

care. A key part of the initiative was to design a primary- and secondary-school health-education program that would address the most pressing public health concerns facing young Mongolians. In partnership with the World Health Organization, the Mongolian government identified ten thematic areas to include in a comprehensive health-education curriculum; one of these areas was reproductive health. ${ }^{2}$

Initially, the Ministry of Health encountered some resistance from the Ministry of Enlightenment about the inclusion of reproductive health and, in particular, the idea of sexuality education. For centuries, Mongolians had avoided public (and much private) discussion of these issues. The hesitation was based in part on a concern that such education would result in promiscuity. Extensive dialogue, joint participation in international meetings, and a review of the literature on this topic led, however, to a consensus that the culture was already in transition, and that effective education could reduce rates of unwanted and unsafe sex. Nergui, Senior Officer in the MOSTEC Division for Policy Coordination of Primary and Secondary Education, explained why reproductive health was included: "Because of changes in politics and life of the society, the risk of STIs, unwanted pregnancies, et cetera is greatly increased. Reproductive health education is one way of addressing these issues."

Jointly, the Ministries established working groups to develop the specific content and curricula for each theme. The goal of the reproductive health curriculum was to enable adolescents to reduce sexual risk-taking behavior, with the ultimate objectives of reducing rates of adolescent pregnancy, sexually transmitted disease, physical abuse, and abortion. Although the Mongolian Foundation for an Open Society provided initial support and technical assistance, by and large, these groups worked on their own with little sense of precisely what they should produce.

The Reproductive Health Working Group was charged with developing a basic reproductive health-education curriculum that would be available to pri-

2 The other topics were: infectious disease prevention; mental health; nutrition; smoking, alcohol and other substance abuse; hygiene and sanitation; physical exercise; healthy lifestyle; oral health, and first aid. 
mary- and secondary-school teachers. Unfortunately, the members worked from outdated information about teenage sexuality and limited information about how social norms such as gender dynamics shape sexual decisionmaking. Furthermore, no one in the group had expertise in education. As Oyun, the physician in charge of the health-education program for the Ministry of Health, explains, "We asked ourselves, 'What did our teenagers need to know?' We didn't have a clue." Nevertheless, the Reproductive Health Working Group, along with the other thematic working groups, published and distributed its draft curriculum to educators nationwide.

\section{The Birth of Po Zorgaa (Project Zero Six)}

To support the implementation of the curriculum and related work in adolescent reproductive health, the government sought to collaborate with the United Nations Population Fund (UNFPA). The resulting Mongolian Adolescent Reproductive Health Project, nicknamed PO Zorgaa, ${ }^{3}$ originally had four components:

- formal education (implementing the curriculum as a pilot program in selected schools and then making it available nationwide);

- informal education (working with nongovernmental organizations to reach young people not in school);

- information and communications (print and electronic media);

- clinical services

In May 1998, two professionals were hired to lead P0 Zorgaa. Altanchimeg (known as Agi), a physician who also holds a public health degree, became the national project coordinator; Oyun- tungalag, a journalist, was hired as the first information, education, and communication (IEC) officer. The following month, as part of a partnership established by UNFPA with the Margaret Sanger Center International (MSCl), An-

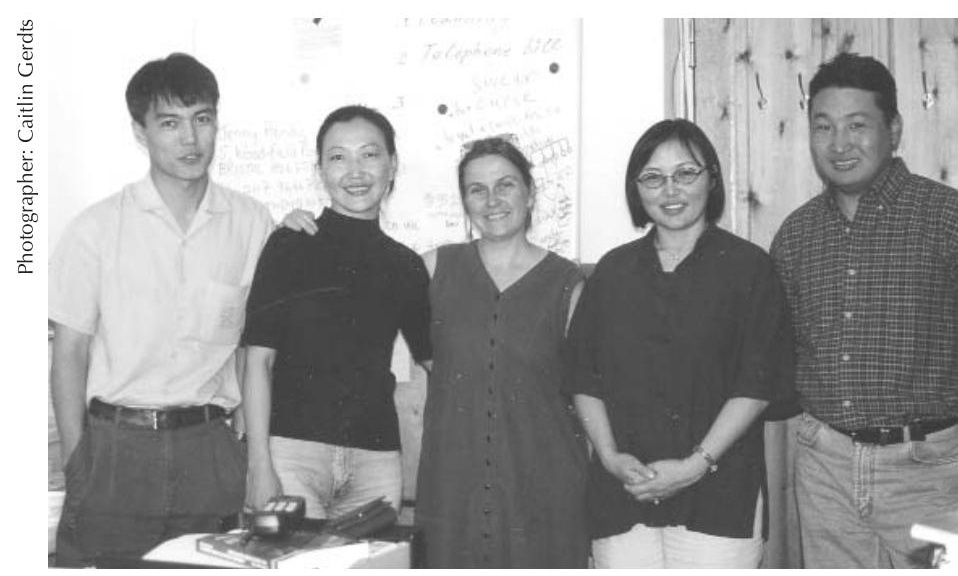

The P0 Zorgaa team faced the task of enabling teachers in every primary and secondary school in the country to provide gender-sensitive sexuality education.

drea Irvin joined the team in Ulan Bator to serve as resident technical advisor.

A baseline survey and a series of focus-group discussions among adolescents helped the team identify the basic knowledge and attitudes of Mongolian adolescents (see the discussion of monitoring and evaluation below). In addition, focus-group discussions with parents and consultations with teachers indicated that both groups wanted young people to have the basic information for protecting their sexual and reproductive health, but that neither group felt adequately prepared to teach this material themselves.

With this information, P0 Zorgaa began its work. Four years later, the school sexuality-education program and a newspaper for teenagers have been the most innovative and successful elements of the project. This issue of $Q / C / Q$ focuses

\footnotetext{
${ }^{3}$ The project's name in Mongolian (Usvur Uyiin Nukhun Urjikhuin Eruul Mend Tusul) was long, so it quickly came to be called by the nickname P0 Zorgaa, which refers to UNFPA Project number 06. (Zorgaa is Mongolian for six).
} 
on what has been achieved and learned from these two activities, particularly from the government's explicit effort to provide gender-sensitive sexuality education to every student in the country from primary through secondary school.

\section{Universal Sexuality Education}

As Agi, Oyuntungalag, and Andrea reviewed the reproductive health curriculum, they developed some serious concerns. First, teachers were reporting that the material was too technical and that they lacked guidance about how to present the information. In addition, much of the information in both the reproductive health and mental health curricula drew on out-of-date materials inherited from the Soviet Union. (For example, the mental health curriculum asserted that childhood masturbation is caused by parasites and that treating the parasites is, therefore, the best way to "cure" small children of masturbation.) Although the government had initially viewed sexuality as a marginal element of the repro- ductive health curriculum, the new P0 Zorgaa team felt it should be placed at the heart of any effort to improve adolescent reproductive health outcomes. One important early achievement was that they and the officials in the government ministries were able to achieve consensus on this matter.

Although the necessity of revising the curriculum was clear, the project staff and their government colleagues realized that there were no sexuality-education experts in Mongolia. They agreed on the importance of international technical assistance, but were committed to building local expertise and enabling the development of culturally appropriate materials. The first decision was that Andrea should train an initial corps of "master trainers," who would become Mongolia's experts on sexual and reproductive health education. These experts would be charged with revising the curriculum, they would learn how to train schoolteachers to teach it, field-test and refine the curriculum, and finally, conduct training sessions for the teachers.

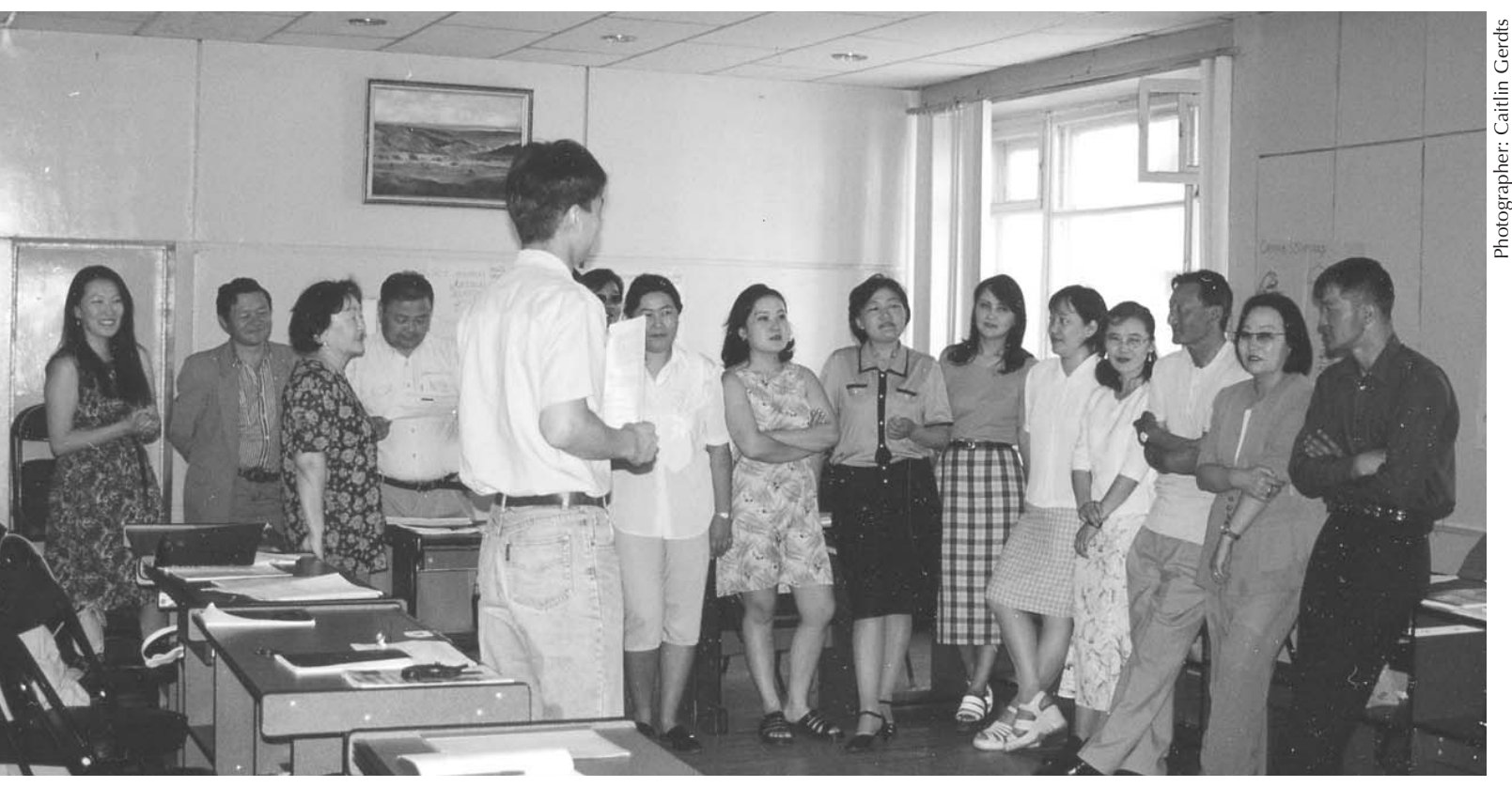

One of the first objectives of the master training was to foster greater ease with the topic of sexuality by helping people to become comfortable with using sexual language. 
The team set about selecting 20 individuals for the master training team. An ad in the newspaper requesting people to apply who were committed to education and the promotion of reproductive health issues for adolescents drew a considerable response. The majority of applicants for the master training were medical doctors. A huge surplus of doctors exists in Mongolia, and many are keen to work in nonclinical programs that draw upon their expertise.

The staff also worked with MOSTEC to select four pilot aimags, or provinces, including the capital city and a western aimag with a significant Kazakh population. Staff traveled to each aimag and met with government officials to select pilot schools in the area. Then they met with the school principals to secure their support and commitment for sending two teachers to the training and providing salaries and time for them to teach the curriculum upon their return.

\section{The Master Training Course}

Along with knowledge of teenage sexuality, the master trainers needed the skills to pass on their information and abilities to schoolteachers in an effective manner. Although elements of the master training course were interwoven, an approximate breakdown of course content included:

- 3.5 weeks on sexuality and gender;

- 2.5 weeks on teacher-training skills;

- one week on counseling;

- Practicum I: 10 hours of practice teaching to secondary-school students

- Practicum II: Two to three weeks of supervised training of schoolteachers

In October of 1999, Andrea taught the first session of the course, beginning with an overview of sexuality. Jenny Hendy, a volunteer from Volunteer Serv- ices Overseas, conducted the teachertraining sessions, and an American social worker facilitated the counseling workshop. The principal aspects of this process are described below.

\section{Sexuality Training}

The government's initial approach to sexuality education had a technical, clinical health focus. The new team embraced a more comprehensive approach.

\section{Participants were asked to list what aspects of their lives they would like the opposite sex to experience. The male participants came up with three items; the women immediately generated a list three or four times longer.}

Accordingly, the training emphasized psychosocial issues, such as defining sexuality and sexual pleasure; communication and decisionmaking in relationships; gender roles; sexual orientation; sexual behaviors, including masturbation; and sexual violence. A secondary but still important aspect of the training focused on technical information including anatomy and physiology; fertility awareness; contraception and abortion; childbirth; sexually transmitted infections; and the sexual response cycle.

Encouraging personal reflection was an essential part of the training. For example, in an exercise about gender roles and socialization, the participants were asked to list what aspects of their lives they would like the opposite sex to experience. The male participants came up with three items: shaving, military service, and the male perspective on relationships. In contrast, the women immediately generated a list three or four times longer, including cooking, child care, 
ironing, shopping, cleaning, and caring for parents. In the ensuing discussion, the women agreed that most men help with household chores, but the men understood the women's frustration that even employed women carry a significantly heavier domestic burden.

Several of the master trainers recall their initial exposure to the course and the process by which they learned to conceptualize sexuality more broadly than they had before they took the course and to assess how each topic related to them personally and to Mongolian culture:

It was very different from what I expected. I had understood before that sexuality is more about sex, only about sex, preventing pregnancy or STIs. During the training I began to understand that sexuality is about the whole of human life.

-Bold, Lecturer in Public Health at the National Medical University of Mongolia

After training I understood (more). . . my attitudes toward sexuality have changed a lot. For example, homosexuality was always very strange to me. I thought it was very wrong, and not a normal thing. Now I can talk freely with other people about these topics. -Oyuntsetseg, Supervising Teacher at the School for Education Development

\section{Training in Counseling and in Participatory Methods}

The master training course emphasized the learners' personal engagement to promote real change. In addition, two modules focused explicitly on interactive approaches, and the trainers used interactive methods throughout the sexuality module. These included modules on counseling and on interactive teaching skills.

A major reason for including training in counseling was that both adolescents and adults were likely to turn to the newly trained and open-minded master trainers with questions and problems. The week-long counseling training included topics such as mental health; counseling versus advice; the role of the unconscious in decisionmaking; setting goals and boundaries in counseling; interviewing skills; assessing individual risk; depression and substance abuse; adolescent development; and the special counseling needs of adolescents. (This last item included a consideration of the emotional needs of gay adolescents; the trainer invited a gay American man to speak about his experience of growing up and to answer questions from the group, most of whom had never met someone whom they knew was gay.) As Oyun commented,

I still remember that feeling of surprise: that counseling wasn't about giving advice, but about being a good listener, about guiding someone to understand their problem and to see by themselves why it is happening and how they feel about it. We had our own circle of four or five trainees who would stay late after the sessions and discuss and role-play the issues from the day. This course was a very powerful experience for me.

The unit on teaching followed a standard "training of trainers" approach, with a focus on sexuality education. Overall, the participants were delighted by the interactive methods they were learning. As Bayar, who replaced Oyuntungalag (but assumed the role of training officer) explained,

I taught at the medical school for six or seven years, but I used traditional teacher-centered methods. Now we focus on more student-centered methods. It's very important for everyone to be comfortable and to create a nice atmosphere. 


\section{Practicum}

Gaining practical experience in teaching was a central element of the master training. Participants went in pairs to schools and universities in Ulan Bator to teach sample lessons. For a total of ten hours, one taught while the other observed, then they reversed roles. The sessions concluded with a peer-critique process. After the formal part of the master training was completed, the second part of their practicum began, involving two to three weeks of practice-teaching to teachers from secondary schools. Andrea and Jenny helped the master trainers prepare, observed their teaching, and offered extensive feedback.

By spring of 2000, eight of the original 20 participants had completed the didactic training and field practicum, observed a teacher-training session, passed an exam, and earned a master trainer certificate. (Eight more had earned a sexuality-educator certificate for completing the course but not the practicum.) Mongolia had a team of master trainers in sexuality education.

\section{Curriculum Development and Testing}

While the master trainers were completing their course and practicum, they began a parallel effort to revise the draft school curriculum for reproductive health. The P0 Zorgaa staff organized a two-week workshop for this process. Bayar described the task they faced:

The main aim was to change adolescents' attitudes so they would practice safer behavior. But we also had to increase their knowledge and skills, for example, their understanding of anatomy and physiology and of STIs, and their decisionmaking, communication, and sex-refusal skills.
The team believed that adolescents needed to begin learning relevant information and skills while still very young in order to protect their sexual and reproductive well-being. The master trainers, therefore, had to assess which topics should be covered with students
As in all countries, language reflects culture; for example, in
Mongolian the word for
"communication" and the word for "relationship" are the same.

of each age group, define the appropriate learning objectives at each grade level, and develop the lesson plans for Mongolia's coeducational schools. They also sought to design a curriculum that would be appropriate or adaptable to the disparate urban and rural lifestyles in Mongolia.

Another task was to identify and use appropriate terminology in Mongolian. This task was complicated because the trainers often worked from English written materials and had to translate them into a language in which there was little public discourse (or shared terminology) about sexuality. Furthermore, as in all countries, language reflects culture; so, for example, in Mongolian the word for "communication" and the word for "relationship" are the same. To ensure they were adopting the best language, Andrea, Agi, and Bayar discussed various concepts and words at length.

A more formidable challenge was limited classroom time. Sexuality was still just one of the ten topics being covered in the government's new healtheducation program. Based on the initial expectation that the reproductive health curriculum would focus narrowly on 
technical topics, the Ministry of Education initially allocated only 22 hours to be spread across eight years-an average of 2.75 hours per year. Andrea explains how they were able to expand that allocation by 50 percent.

Because so many hours in the original mental health curriculum were used to address sexuality and life-skills issues, we spoke with the mental health working group and asked if we could revise their lessons together, joining their 11 hours to ours, which they agreed to do. Additionally, the working group for infectious diseases was allotted three hours to address sexually transmitted infections and HIV/ AIDS, so we asked that group if we could include those lessons in our revised curriculum, to which they also agreed. This gave us a total of 36 hours to work with.

Thirty-six classroom hours over eight years-a total number of hours roughly equal in duration to a 45-minute class meeting twice a week for a single semester-is still low by the standards of most experts. ${ }^{4}$ This amount of time is certainly not enough for making the kind of impact the project was designed to have. But the trainers hope it can begin to influence adolescents' knowledge base and attitudes and establish a precedent from which to grow. (See sections below on Encountering Realpolitik and on Ongoing Challenges for further discussion.)

\section{Deciding What Adolescents Need to Know}

The staff had conducted focus-group discussions among young people to learn what issues were of greatest interest and concern to them. They did not, however, depend on the students for input regarding specific content. Asking adolescents about their concerns was seen as more useful than asking them to identify what they would like to learn about a topic about which they have little understanding.

The master trainers also relied on their own learning experience. Having just completed an extensive course in sexuality and reproductive health, they reviewed notes from their training to help them decide which topics were most relevant and which exercises were most effective. They paid renewed attention to how their own experiences and attitudes colored their views about what information was important. The group divided into teams of three to four people, with each team taking responsibility for drafting lesson plans for a certain number of topics. After heated discussions, the team came to consensus; the most challenging decisions focused on which topic was most appropriate at each grade level and on the design of lessons for exploring values.

The group recognized that although students needed basic factual information, the most challenging topics were not the technical ones, but rather, the social and psychological factors that affect sexual decisionmaking, for example, gender dynamics, body image, and the desire for love.

\section{An Emphasis on Gender}

Among the topics that proved most challenging were those related to gender roles, a thorny topic for the group. Because Mongolian women are generally more educated than men and often have higher earning power, a sense exists that some problems are related to gender. The curriculum-development team grad-

\footnotetext{
${ }^{4}$ For example, the FLASH (Family Life And Sexual Health) curriculum for grades 5-12 contains 83 lessons; the Advocates for Youth "When I'm Grown: Life Planning Education" K-6 curriculum includes 201 activities. According to Andrea Irvin, many health educators argue that an hour a week is a rule of thumb for effective health education.
} 
ually recognized that the experiences of females are different from those of males and that this difference matters fundamentally in issues of sexuality and reproduction. Several of the master trainers alluded to this concern:

Especially in the countryside, there are strict gender roles. And still, in society, among decisionmakers, very few are women.

— Bold, a male trainer

(Domestic violence) is fairly common, but it's not always clear if people know what is or is not domestic violence.

$$
\text { - Bayar }
$$

The curriculum the team agreed upon contains two lessons that focus directly on gender issues, that is, that seek to provide learners with a greater sense of how gender functions at individual, interpersonal, and societal levels. Many of the lessons on other topics are seen through the "lens" of gender. Thus, to teach the curriculum, schoolteachers must be trained to analyze how gender dynamics affect a wide range of other issues, such as sexual decisionmaking, sexual pleasure, and the risk of violence. The team began to appreciate that they were dealing with a constellation of intersecting social and technical topics, and that gender issues were often at the heart of that intersection. As Bayarmaa, a female gynecologist and specialist in adolescent medicine on the team, pointed out:

The most important things (to teach about are) contraceptive use and getting sexual pleasure. Many people think contraceptive use and unwanted pregnancy depend entirely on the woman, that they are not men's responsibility. We need to change that. Women need to learn how to get pleasure from sex. They have to know that the clitoris is their most sensitive organ for sexual pleasure.
There was some discussion among the trainers that boys and girls might best learn about some issues in sex-segregated groups. The teachers told them that holding segregated classes would not be practical, however. The team agreed that, given the level of depth into which teachers can go in the current number of hours available, both boys and girls benefit from receiving all of the information offered.

\section{Selecting Topics for the Curriculum and for Each Grade Level}

As a guide, the team followed the basic structure of their own master training and the curriculum guidelines developed by the Sexuality Information and Education Council of the United States (SIECUS), which groups topics under six themes: society and culture, relationships, personal skills, human development, sexual behavior, and sexual health. Most of the 37 topics selected fall under the social rubric of self and others-helping young people consider basic issues of adolescence, gender roles, and decisionmaking. The technical topics such as anatomy, physiology, and contraception, which comprise much of traditional sexuality education elsewhere, account

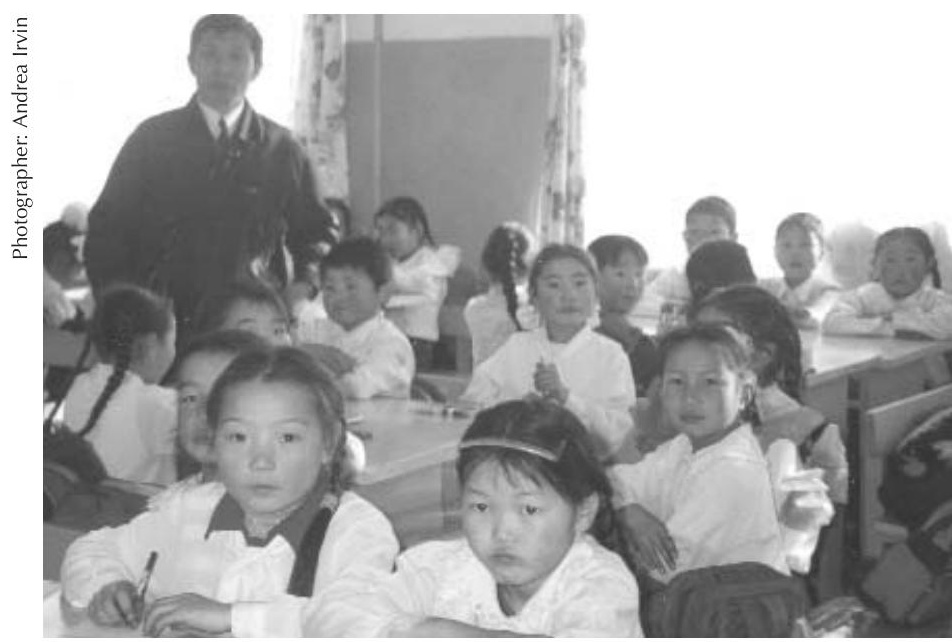

The curriculum calls for third graders to learn about gender roles, their bodies, and emotions. 
for a minority of the topics in the Mongolian curriculum (see Table 1).

After the list of topics was devised, the master trainers sought to agree on what information would be appropriate for each grade level. Although classroom hours were limited, the team planned to introduce some sexuality education in grade three (students aged 9-10) and to maintain continuity and reinforcement through grade ten (the final year of secondary school). To establish a basic structure and to gather further content for this eight-year program, the team relied on references that came primarily from Western models. ${ }^{5}$ Although the team adapted these prototypes to build their curriculum, they also drew on their experience as Mongolian parents, clinicians, teachers, and, of course, former adolescents.

\section{Paying Attention to Details: Multiple Revisions and Collaboration with Schools}

The most time-consuming phase of launching the sexuality-education program was the extensive editing and revision of the curriculum. The team revised the draft curriculum numerous times, based on field-test results and on feedback from government officials. To encourage teachers to replace the old curriculum with the new one, P0 Zorgaa staff and trainers also invested time and resources to make the new curriculum attractive and user-friendly, aspects of the product that had been field-tested.

The project also made efforts to foster successful implementation at the local level. As a centralized project with no field staff, the PO Zorgaa work plan had not allowed for significant communitylevel input at the conceptual stages. The project staff worked closely, however, with school leaders to enhance imple-

\section{Table 1}

\section{Topics Originally Selected for the Curriculum}

\author{
General Adolescent and \\ Psychosocial Topics \\ Gender roles \\ Self-esteem \\ Personal values \\ Defining human sexuality \\ Messages about sexuality \\ Expressing emotions \\ Friendship \\ Love \\ Sexual identity \\ Marriage; life commitments \\ Family or domestic violence \\ Planning for the future \\ Sexual relationships, sexual behavior \\ (including pleasure) \\ Masturbation \\ Decisionmaking about sex \\ Abstinence \\ Communication and consent \\ Risk assessment \\ Safer sex and alcohol \\ Styles of communication \\ Peer pressure \\ Refusal skills \\ Child and sexual abuse \\ Sexual violence (rape, date rape) \\ Sexual harassment \\ Stress \\ Diversity
}

\section{Technical Topics}

Anatomy and physiology

Puberty

Menstruation

Breast and testicular self-examination

Conception and pregnancy

Prenatal care

Contraceptive methods

Abortion

STIs/HIV/AIDS

Safer sex and condom use

Human sexual response

\footnotetext{
${ }^{5}$ These included SIECUS' Developing Guidelines for Comprehensive Sexuality Education; the Seattle, Washington FLASH (Family Life And Sexual Health) Curriculum for grades 5-12, and the Center for Family Life and Education.
} 
mentation. They met with school administrators to negotiate the schools' commitment and participation and to identify criteria for teacher selection, and they developed a pamphlet for schools to give parents that defines sexuality education and describes the government's program.

\section{Encountering Realpolitik: Decisions about Time and Content}

In many settings, conservative segments of society launch campaigns against sexuality-education programs. Although this was not an overriding concern in Mongolia, Ministry officials felt responsible for considering potential risks and pitfalls that could trigger a backlash against the curriculum. The Ministries gave initial approval to the curriculum in June of 1999, but the P0 Zorgaa staff and master training team faced two constraints on the scope of their work.

The most serious limitation was the classroom time allotted for teaching the curriculum, even with the increase to 36 hours. The range of topics simply did not fit into 36 hours. Although the master trainers, along with many teachers and students, wanted more time for the classes, they felt that building the program was most important and that a gradual expansion would reduce the likelihood of causing a negative reaction. Still, Bayar would like to see the number of hours doubled at least. Agi agrees, adding:

At present, there are too few hours for us to reach our objectives for sexuality education in secondary schools. We need to advocate with the government, and when they revise the standard hours in 2003, we must use this opportunity.

The second constraint concerns content. With officials from the Ministries of Health and Education, the project team worried that some of the topics might be considered too controversial (or, in some cases, not essential) for inclusion in the required curriculum. Predicting whether a vocal minority will protest a sexualityeducation program is never easy, but because community-level consultation during the establishment of P0 Zorgaa was limited, its leaders were especially cautious. Guided, therefore, by a sense that maximizing the likelihood of the project's acceptance among the nation's schoolteachers and parents was advisable, the team designated eight potentially sensitive topics as elective elements of the curriculum. (Table 2 shows topics that remained in the mandatory core curriculum.) The reclassified topics were: sexual

\section{Because of concerns that some topics might be controversial, the team designated eight potentially sensitive topics as elective elements of the curriculum.}

harassment; child sexual abuse; decisionmaking about sex; abortion; masturbation; family or domestic violence; human sexual response; and responsible sexual relationships. As Agi explained, "Because it was our first experience, we thought it was better to be cautious. If we caused a big negative reaction, it could kill the whole program." Withdrawing these eight topics from the standard curriculum also resolved the problem of how to fit the required curriculum into 36 hours.

In some ways, the reclassification of certain topics as electives was a major setback in the development of a comprehensive sexuality-education program. The training team and their colleagues in the government held extended discussions about whether to reclassify any of the topics and about which ones were most appropriate to designate as elec- 


\section{Table 2}

\section{Topics by Grade Level in the Final Curriculum}

\begin{tabular}{|c|c|c|}
\hline Age & Grade & Topics \\
\hline $9-10$ & 3 & Gender roles; anatomy and physiology \\
\hline $10-11$ & 4 & $\begin{array}{l}\text { Feelings; puberty changes (physical and emotional); } \\
\text { menstruation; wet dreams }\end{array}$ \\
\hline $11-12$ & 5 & Friendships; peer pressure and decisionmaking; self-esteem \\
\hline $12-13$ & 6 & $\begin{array}{l}\text { Society and messages about sexuality; communication basics; } \\
\text { assertive communication; values }\end{array}$ \\
\hline $13-14$ & 7 & $\begin{array}{l}\text { Diversity; love; communication and consent; } \\
\text { managing stress; rape; date rape }\end{array}$ \\
\hline $14-15$ & 8 & $\begin{array}{l}\text { Anatomy and physiology II; conception and pregnancy; } \\
\text { abstinence; condoms; contraception; breast/testicular self-exams }\end{array}$ \\
\hline $15-16$ & 9 & $\begin{array}{l}\text { Communication about safer sex and condom use; } \\
\text { refusal skills; sexual identity and orientation; } \\
\text { sexual relationships and behavior; risk assessment; } \\
\text { safer sex and alcohol }\end{array}$ \\
\hline $16-17$ & 10 & $\begin{array}{l}\text { Marriage, commitments, and rearing children; } \\
\text { goal setting; prenatal care and childbirth; } \\
\text { sexuality through life cycle; STIs and HIV/AIDS }\end{array}$ \\
\hline
\end{tabular}

tives. Although the team recognized that categorizing some topics as optional made the curriculum less comprehensive, the program was understood to be taking an enormous first step. Sexuality and reproductive health issues had not been discussed publicly anywhere in modern Mongolia, and the government was still adjusting to the idea of educating students about sexuality. Moreover, many controversial topics remained in the standard curriculum, and the elective topics have not been censored. The materials for the optional lessons are included in the published curriculum, and the master trainers still teach the electivelesson topics in their teacher-training courses. Indeed, the master trainers ex- plain to the teachers why these topics are classified as elective and explore why these issues they raise are sensitive ones. As one of the master trainers, Bold, comments, "My favorite part is to teach difficult topics like sexual orientation. Teaching about attitudes is very different for Mongolians. We talk about knowledge and skills, but attitudes are hard."

The final decision about whether the elective topics will be offered rests with each teacher (or in some cases, with the school's principal), and generally depends on his or her own comfort level and the comfort level of the students. ${ }^{6}$ Bayar believes that many teachers will choose to teach at least some of the elective topics. He says, "Mongolians

\footnotetext{
${ }^{6}$ The presentation of these units is accompanied with the following explanation from the Ministries of Health and Education: "Besides the official lessons, we have developed the following topics for elective hours and for answering questions that may be raised from students."
} 
are very open people. If they don't know about something, they are willing to learn. So when we teach information on new and controversial topics, they start to think about it rather than just argue."

Another master trainer, Bayarmaa, shares Bayar's optimism. She explains that the team is taking the long view: "Mongolia has a tradition of not talking about these issues, like abortion and masturbation. We are trying to change that."

Bayar and Bayarmaa may be right. The Mongolian government can hardly be accused of putting its head in the sand or promoting a narrow abstinenceonly approach. Even an official at the Ministry who was originally unsure about including sexuality in the healtheducation program has since become a strong supporter of P0 Zorgaa and is holding it up as a model for how the government can develop and implement curricula for the other health-education topics in a systematic and thoughtful way.

\section{Training for Teaching Young People}

In the summer of 1999, four master trainers conducted the first teacher-training for 25 teachers from the 12 pilot schools. Most Mongolian schools now have designated health educators, and most of the training participants are from this group. ${ }^{7}$

The structure of the two-week teachers' training resembles the training that the master trainers received; it includes a dual focus on the sexuality-education curriculum and on participatory teaching. It is less intensive because schoolteachers are not expected to become national experts on adolescent sexuality or train teachers themselves. The lessons have been modified and developed us- ing examples from traditional and modern Mongolian culture. Like the master trainers, the schoolteachers are enthusiastic about the participatory learning climate, which is radically different from the didactic lecture style that is typical in Mongolian schools.

At the same time that the master trainers began to work with teachers, the plan to distribute the curriculum to the pilot schools only was altered. Implementation of the national healtheducation plan was under way, and many teachers were already using the original and inadequate reproductive health curriculum. The Ministry of Education argued that, given the enormous investment in developing the new curriculum and the quality of the materials prepared for it, all schools should receive it-even before their teachers had been trained to use it. Therefore, even as the project staff conducted a formal assessment of the curriculum among trained teachers in the pilot schools, they simultaneously provided the printed curriculum to every secondary school in the country as a resource. As Andrea commented, "You plan carefully for things to be one way, but then reality is always more complex."

To ensure that every Mongolian student learns about reproductive health and sexuality from a well-trained teacher, the master trainers are working to develop a corps of specialized health-education teachers who have learned to teach this curriculum specifically. Therefore, once the first group of schoolteachers began teaching the curriculum, the trainings expanded to include teachers from schools not in the pilot aimag, as well as some health professionals. The government's goal is to provide each of the 683 secon-

In addition to the designated health-education teachers, some third- and fourth-grade teachers attend the training, because for those grades, the grade teacher provides health instruction. Where possible, P0 Zorgaa training stresses criteria for selecting teachers: an interest in teaching about sexuality, an openminded and nonjudgmental style, an approachable manner, good communication skills, and involvement with young people beyond school. 
dary schools in Mongolia with at least one qualified sexuality educator on staff. As of early 2002, the master trainers have trained about 300 secondary-school

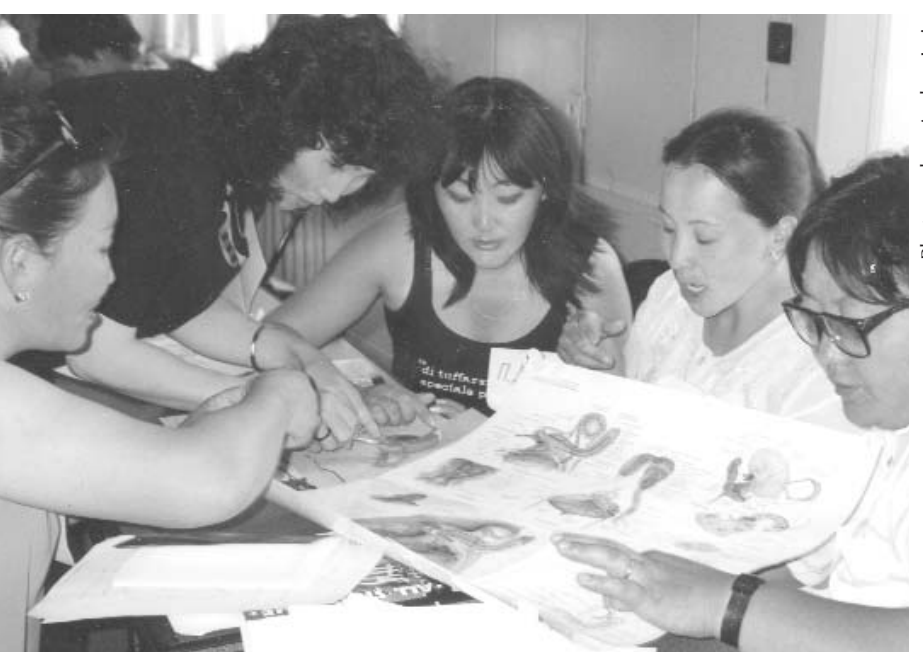

To institutionalize sexuality education in teacher training, all students training at the Pedagogical University to become primary-school teachers are required to take a 60 -hour course on reproductive health and sexuality education.

teachers; however, at least an equal number of teachers are using the curriculum without the benefit of training. Nergui estimates that close to 60 percent of schools are now offering the curriculum.

Another important achievement has been the project's collaboration with the Ministry of Education to institutionalize sexuality education in teacher-training programs. The Pedagogical University in Ulan Bator now requires all students training to become primary-school teachers to take a 60-hour course on reproductive health and sexuality education. The university also has begun to offer a course on these topics for biology teachers. The P0 Zorgaa staff hope that the university will eventually offer health educationincluding coursework in sexuality education-as a specialization within the standard curriculum for teachers in training.

\section{Reaching Young People}

Typically, the sexuality-education curriculum is offered within classrooms, but some teachers continue offering the course after the school year is finished. One morning in late June, Narantogtokh, one of the original pilot teachers, conducted a session on gender roles at Nairamdal summer camp for a group of about 60 12-year-olds.

The group included young people from across Mongolia, but the majority lived in and around the capital. Most of their schools had already begun to implement the curriculum, so for this session, Narantogtokh adapted two popular lessons generally taught in the younger grades. The first was a group exercise on gender roles. Narantogtokh facilitated a forced-choice exercise, designed to inspire reflection on aspects of gender that the students may have taken for granted. After asking a few nonthreatening warmup questions, she read the students a series of statements related to gender, including, for example:

- If a boy invites a girl on a date, he must pay for everything.

- Mothers should take more care of their babies than fathers.

- Girls need education more than boys do.

After each statement, the students considered whether they agreed or disagreed, and demonstrated their choice by walking to the side of the room designated "agree" or the other designated "disagree." Those who could not decide were allowed to stand in the middle. The students then argued in defense of their choices before moving on to the next statement.

The last statement to be put forth sparked the most debate: "Girls should not say 'I love you' first." All but three girls moved to the "agree" side of the room. For ten minutes the three female dissenters held fast to their belief that girls should be as free as boys to express their feelings, despite opposing arguments defending Mongolian tradition 
whereby boys are always the first to declare love. They asked, "Why does it have to be like that?" and "What if the girl feels like saying it first?" By the end of this discussion, the two sides had evened out: While some girls stayed on the "agree" side, a number of boys had crossed the line to the other side.

At the end of the exercise, Narantogtokh asked the students about the nature of stereotypes in general. The students were quick to volunteer their opinions, commenting, "stereotypes are assuming things about people" and "a lot of times stereotypes are wrong." Drawing on the debate about who may say "I love you" first, Narantogtokh helped the students examine the ways in which we accept unquestioningly as "tradition" and, in so doing, perpetuate stereotyping.

The second lesson concerned communication, specifically how one distinguishes among expressing oneself passively, assertively, and aggressively. The lesson began with a demonstration of ways to ask for a pencil, then extrapolated to communication within intimate relationships.

After these group exercises, Narantogtokh distributed an issue of the P0 Zorgaa newspaper UerkheLove that concentrates on gender issues. At first, the students' embarrassment was palpable; the room filled with blushing cheeks and occasional laughter. Within five minutes, however, the group was nearly silent-every student with a newspaper in hand or peering over the shoulder of a friend, deeply engaged in UerkheLove.

\section{Response from the Teachers}

In-depth feedback was provided by the teachers in the pilot schools, who returned to Ulan Bator a year after their training to discuss the curriculum. Dashtsermaa, a chemistry teacher in Tuv aimag 45 minutes outside the capital, recalled teaching her fourth-grade students the lesson about menstruation. Mongolian girls do not discuss menstruation openly, and most adult women say that when they were young, it was an uncomfortable topic to bring up even with older women in the family. Dashtsermaa commented, "The girls were asking about things they really needed to know, and I realized just how important it is for them."

The teachers who received the training along with the curriculum have provided much positive feedback. Their primary concern remains that they have too few hours allocated to sexuality education, as well as too few materials with which to teach it.

\section{Response from the Students}

The students, too, are notably positive about the program. The following comments are typical of those offered:

Before, we couldn't get information; we couldn't talk to our parents or other adults. The only way to get information is from classes or from the media, and the media doesn't give us correct or understandable messages about sexuality.

- Delgerdalai, a teenage girl from

Tuv aimag

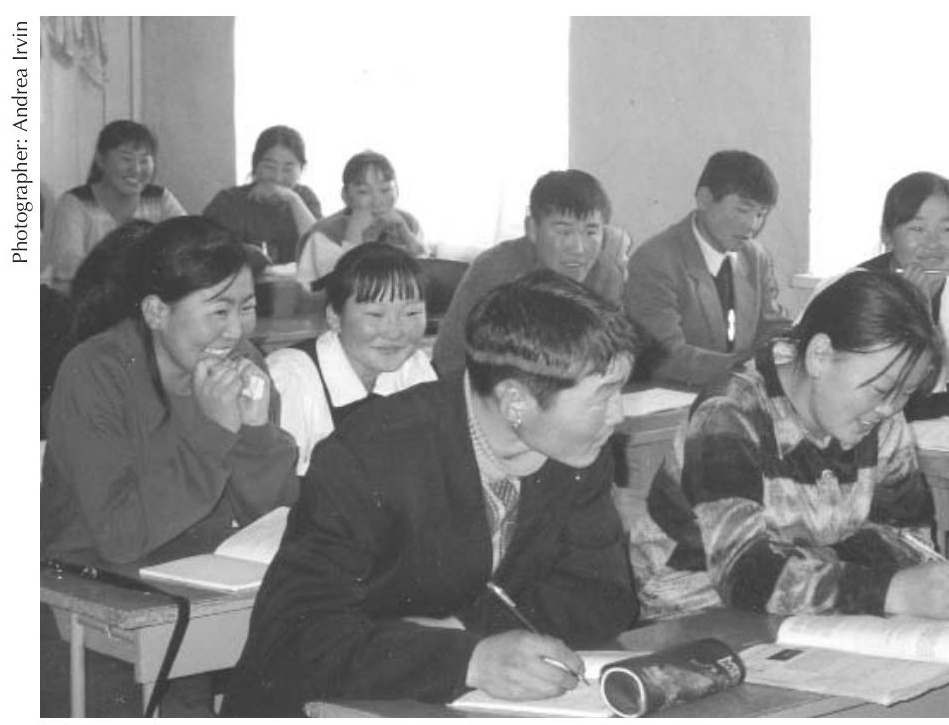

The curriculum engages students in lively interactive exercises, but the learning objectives are serious. As one student remarked, "After the discussions, I think the boys started to think about the realities of gender roles in a family and in relationships." 


\section{The Teen Board}

Although P0 Zorgaa initially took all the volunteers they could find to form a teen board for UerkheLove, now many more teens want to join the board than there are spaces available. Staff seek to ensure that the board is made of individuals-male and femalewho have writing skills or are interested in journalism and who seek an opportunity to work in teams and to grow personally from their involvement. Eight members of the teen board sat down one Friday afternoon to explain their excitement about their work:

In high school, reproductive health education is so limited. This newspaper focuses on adolescents, and almost all other newspapers focus only on adults. As a teen board member, I can form close relationships with other adolescents, and I can understand the issues myself and share with others.

- Ariuntuya, 19-year-old girl

We will all be parents one day, so we need to know this information for our children too. Teenagers can learn communication skills and how to love and respect each other. (This) program is really needed for our future.

— Erkhemtuya, 17-year-old girl

These teenagers debated which sexual and reproductive health issues are the most difficult for adolescents in Mongolia. The girls were the most vocal, and their comments echoed those of the young people at the summer camp, emphasizing STIs, sexual decisionmaking, unwanted pregnancy, and sexual violence.

Although they recognize the problems that they are facing, these eight young people and their fellow board members are proud and optimistic. They believe that through the newspaper they have created a forum that is, for the first time in Mongolian history, providing adolescents across the country with correct information about critically important issues. As Ariuntuya states:

When we write the newspaper, we try to explain things in a way that teenagers will understand it. It's for them, not for adults. When we meet with teenagers in the countryside, they just shine and shout at each other, because they are getting the information for the first time from our newspaper. They can't get it anywhere else. In my experience, people who have problems get information from the newspaper, and now they can start to fix them.

Her friend Erkhemtuya is equally proud: "We have many readers, and lots of students read the paper and send questions. Our readers are increasing day by day." She adds that classroom sexuality education benefits from the popularity of the newspaper, stating, "My class really liked the reproductive health lessons, partly because they're related to our newspaper."

ing directly to the "Teen Voice" page. The newspaper was called UerkheLove, which translates loosely as "intimate love."

UerkheLove is published four times a year, each issue focusing on a single theme. Past issues have addressed such themes as gender roles, communication, body image, mental health, setting goals for the future, adolescent pregnancy, substance use, and violence. The eight-page publication is organized so that the first three pages carry substantive articles and editorials concerning the central theme; the following two pages contain interviews and articles on popular culture; page six carries a question-and-answer column, "Dear Hulan"; page seven offers "Teen Voices" (opinions, poems, and so forth); and page eight provides announcements, resources, and information for parents. For example, the September 2001 issue was called "What can you do to avoid violence?" (see page 26).

With each issue of UerkheLove, the teen board has assumed a more integral 


\section{UerkheLove Special Issue: What Can You Do to Avoid Violence?}

Substantive articles included:

- "Your body is yours"

- "Let's talk about sexual violence" (What is it? Types of sexual violence; the right to privacy; consequences of violence; eight rules for avoiding violence; how to help your friend; when a boy is affected by violence; trust your child and answer questions.)

Teen editorials included:

- "Is it their fault? Some thoughts on homeless children"

- "Report from an HIV/AIDS conference I attended"

- Book review: The novel Give Me One Kiss and I Will Go

"Dear Hulan" questions included:

- "I live in a remote area and have been repeatedly raped by my uncle, my period is missing, and I have discharge from my vagina. What shall I do?"

- "When I kissed her she liked it, but suddenly she ended the relationship. Is it true that when girls say no, they really want it? Do they have satisfaction when they're raped?"

Additional resources included:

- "Do you know about it? A test on violence issues"

- "Talking about education and knowledge: Quotes from the poet Ts. Khulan, the popular singer B. Sarantuya, and the composer B. Dolgion.

role in the paper's development. Currently, adolescents are writing parts of the question-and-answer page. After deciding which questions they can answer, members of the board consider the topic, find the answers, and respond in a way that provides accurate information and is accessible to their peers. The articles are checked for accuracy and quality.

UerkheLove is distributed free, primarily through schools and by youthoriented nongovernmental organizations. A small number of copies are also distributed through health providers, the teen board, and directly from the project and the UNFPA field offices. The newspaper is reaching an enthusiastic audience. In Andrea's words:

It took off like a house on fire. The kids loved it ... the adolescent board made sure it was something that kids really wanted and were interested in, and they did a lot in terms of developing contributions themselves. For the first issue we printed 5,000 copies, and then 10,000, then 15,000, then 20,000. People kept saying, "It's not enough!" For the last five editions of UerkheLove, we have printed 100,000 copies-one for every five adolescents in Mongolia.

Members of Parliament and provincial governors have asked the project to provide them with copies of every issue so they can distribute it to their constituencies, and one parliamentarian praised the publication explicitly in an official speech. Although a few adults have questioned the appropriateness of the newspaper for children, in general, adults in the community have been pleased with it and request copies for their children. As one prominent member of the community explained, "I usually put it in the bathroom. I have two teenage sons, but because I can't talk to them openly, I give them the newspaper ... so they will have correct information." 
According to Erkhemtuya, a board member, the teachers also appreciate the availability of a resource that complements their classroom lessons. She recalls that some of her teachers say, "you should read this newspaper very carefully. It is very important for your future."

\section{Monitoring and Evaluation}

Even under the best circumstances, documenting the impact of an education program on the target population's sexual and reproductive health is difficult. If positive outcomes occur, how many of them can be attributed to the program rather than other social factors? If no impact is measurable, is that the result of allocating too few hours to an otherwise well-designed and important curriculum? In the case of Mongolia, resources are not currently available for the kind of complex assessment that the government could use to determine the long-term return on its investment in sexuality education.

Nonetheless, the project has implemented a number of measures in the effort to gauge the outcomes of its efforts. Before classroom education began, the project staff, in collaboration with the National University Population Teaching and Research Center, designed a baseline survey documenting students' knowledge, attitudes, and behavior, as well as their characterizations of their relationships with their parents and the sources of their information about sexuality. More than 1,400 students completed this survey. Moreover, project staff conducted 17 focus-group discussions to gather more qualitative, in-depth data on the affective aspects of these issues, including discussions with parents about their desire for school-based sexuality education. Analyzing the data and completing the report of this base- line study has been a major undertaking, but preliminary analysis revealed a pattern not unlike that in many countries, including:

- high acceptance of premarital sex among both boys and girls, but greater acceptance of sexual experience for boys than for girls;

- higher levels of information about contraceptives (including condoms) among girls;

- greater discomfort in obtaining condoms and negotiating their use among girls;

- friends and media as primary sources of information about sexuality; and

- strong support among both students and parents for sexuality education at school.

The original plan was to repeat the baseline survey in the pilot areas within two years of initiating classroom sexuality education. Project staff feel that repeating it so soon would be premature, because the curriculum is undergoing revision and the material is still new to the teachers. Without those results, UNFPA is relying primarily on site visits and staff consultations to gather information and assess the future direction of its support for adolescent reproductive health.

For its part, the government is proud of P0 Zorgaa and hopeful about its future. According to Nergui of the Ministry of Health, "(For) the next UNFPA country program (2002-06), we have discussed strategies to strengthen and sustain this project. I hope this project will continue and become a sustainable part of the curriculum." Linda Demers, the UNFPA Representative who has worked closely with the government and the P0 Zorgaa staff, is similarly optimistic: 
UNFPA considers the P-06 project as one of our success stories in Mongolia. This project is bringing new approaches to sexuality education, and stimulating strategic changes in the way sexuality education is dealt with; and truly building national capacity. A critical element in the success of this project has been the continuous partnership and dialogue between the government, the UNFPA Field Office, the project staff, and other partners, combined with a continuous critical reassessment of the project. We never took anything for granted, and we always tried to refine our approach. P-06 has put in place a solid foundation to build on; in its new five-year program, UNFPA will fund the expansion of the successful pilots and continue support to sexuality education and IEC - taking into account the lessons learned from $P_{-}$ 06 and filling in the gaps. (The UN Foundation supports UNFPA for a complementary project including clinical services and education efforts for parents and out-of-school youth, for example.)

\section{Ongoing Challenges}

The Mongolian Adolescent Reproductive Health Project-P0 Zorgaa-has created a foundation for enabling the next generation of Mongolians to promote their own sexual health. From a policy perspective, P0 Zorgaa is already a significant success story: The project is enjoying far greater parental support than anyone had anticipated, and it has been successfully integrated into teachertraining programs. Despite the enormous credit the Mongolian government merits for these achievements, UNFPA, government officials, project staff, and the master trainers are acutely aware that the project must face a number of challenges if it is to achieve its potential.

\section{Increasing Classroom}

\section{Hours for Sexuality}

\section{Education}

The staff and the master trainers are aware that five or six hours a year of sexuality education will have little or no impact on behavior. Even with the input of UerkheLove and the devotion of trained teachers who spend a significant portion of their total health-education time teaching about sexuality and reproductive health, the government will need to expand the number of allotted hours to provide what may be considered "comprehensive sexuality education." The Ministry of Education plans to revise the allocation of hours in 2003, and project staff are planning an advocacy campaign to increase hours. They are hoping that the lessons learned about the pedagogic requirements for sexuality education, along with the project's track record, will facilitate an expanded time allotment. Clearly, such an increase is essential if the program is to achieve its promise and justify the investment in its careful development.

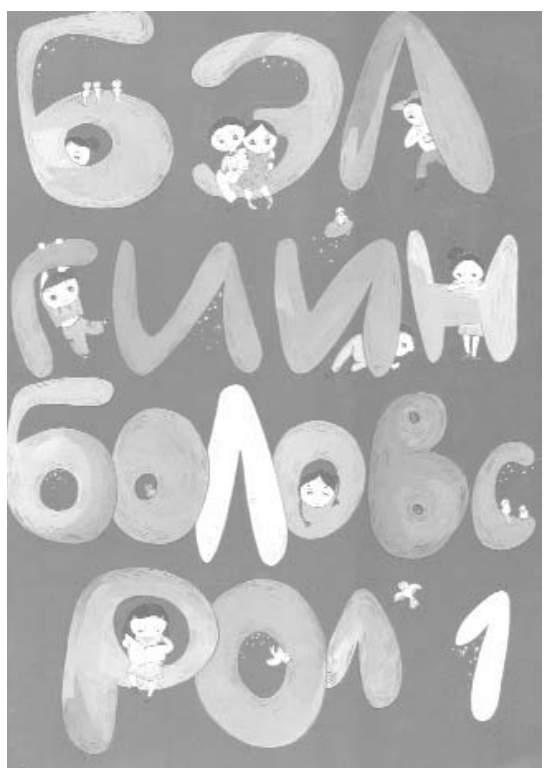

P0 Zorgaa has developed two local texts to complement the curriculum. This one, aimed at primaryschool children, is titled "Sexuality Education." 


\section{Revising the Curriculum}

The curriculum distributed nationally contained some minor errors and poor examples, which have been corrected. When more experience has been gleaned and if the government expands the number of hours for reproductive and sexual health education, a second edition of the curriculum will be produced and distributed nationally. As more hours become available to teachers and broad community support for the project is documented, the elective topics-some of which are a critical part of sexuality education-may be reconsidered for the core curriculum.

\section{Developing More and Better Resources for Adolescents}

There is still a dearth of written materials currently available to young people. To address this need, the project has developed two local reference texts, one for primary school and one for secondary school, to complement what students are learning from their teachers. In addition, the project has translated two English-language books. ${ }^{8}$

\section{Developing Resources for Parents}

Although the project staff did not work closely with the community in building political support for sexuality education, early discussions held with parents indicated support for implementing a curriculum in the schools. Staff have, nevertheless, been struck by how uniformly positive parents' response has been. In more than three years, only one parent has called to complain (about the newspaper), and negative feedback from schools has been rare. P0 Zorgaa staff understand that they are dealing with sensitive issues and that deeper investment in the community of parents can make a valuable contribution. Staff see a particular need to support parents' own knowledge base, both for parents' own well-being and in order to foster communication with their children and support for their children's education.

To this end, in collaboration with UNESCO and MOSTEC, the staff have developed a book that aims to help parents communicate with their adolescent children about issues related to sexuality. The book contains both didactic information and related exercises and will

\section{Staff have been struck by how uniformly positive parents' response has been. In more than three years, only one parent has called to complain.}

be used as part of a MOSTEC distanceeducation program that also includes radio programs and classroom sessions. In the distance-education program, parents read the book and complete the exercises on their own, listen to the radio broadcasts, and meet thereafter with tutors and other parents in classroom settings. P0 Zorgaa staff believe that community support of sexuality education for adolescents will be enhanced as parents are given a chance to participate in learning and in teaching their children.

\section{Developing Clinical Services for Adolescents}

Other than a few clinics in Ulan Bator, few places exist where teenagers feel

\footnotetext{
${ }^{8}$ It's Perfectly Normal is by Robie Harris, published by Candlewick Press (1996). How Sex Works is by Elizabeth Fenwick and Richard Walker, published by Dorling Kindersley (1996).
} 
comfortable about seeking reproductive health-care services. Although the existing clinics technically are open to adolescents, most teenagers report that they are concerned about their privacy, because local populations are small and "people talk." Adolescents seeking serv-

The Mongolian government has begun to implement a universal project in the schools that will eventually reach every child every single year in grades three through ten.

ices report that doctors have been rude to them. P0 Zorgaa staff are cooperating with a sister project, also funded by UNFPA, to open eight confidential, adolescent-friendly pilot clinics this year. Each clinic will have a teen board.

\section{Reaching Out-of-school Youth and the Broader Community}

The initial project plan called for the Margaret Sanger Center International and UNFPA to expand the capacity of nongovernmental organizations (NGOs). The NGOs were to work with different communities to extend the reach of the curriculum. P0 Zorgaa conducted a three-week training course for NGO staff and volunteers in 1999, and the project distributes materials such as UerkheLove to the NGOs. Because of financial constraints, however, this element of the project has not yet been developed, and the curriculum is not yet reaching the large number of out-ofschool adolescent boys, for example. Improving upon early efforts to produce radio and television programs will also help the program expand its reach.

\section{Lessons Learned}

The Mongolian government, responsible for fostering the well-being of a diverse population ranging from nomadic herders to sophisticated urbanites, has taken a clear look at the present and courageously affirmed its commitment to the future. To this end, it developed a cadre of national trainers in the fields of sexuality and reproductive health. These trainers have designed an up-to-date, culturally appropriate curriculum that places issues such as gender roles and self-esteem at the core. They have begun to implement a universal project in the schools that will eventually reach every child every single year in grades three through ten. They have established a place for the most controversial topics, and have won over skeptical officials.

Mongolia is beginning to receive the attention its deserves for the first stages of its reproductive health and sexualityeducation program. A considerable effort must be made if the program is to achieve its goal: providing the young with the information and skills they will need to negotiate their way through a changing culture and to protect their sexual health. Nonetheless, valuable lessons can be derived from this program for leaders in other countries seeking to implement a thoughtful and effective sexuality-education program:

- Even in settings where gender inequity is relatively moderate, issues such as unwanted sex and gender roles are among adolescents' especially girls' - most pressing concerns.

- In settings with relatively high adolescent literacy rates, written materials remain a relatively inexpensive and effective means for providing teenagers with informative and thought-provoking material.

- Authentic local expertise is key to a program's being culturally relevant 


\section{Resumen en Español}

El interés que tantos países muestran hoy por los programas integrados de educación sexual tiene varias causas: la extensión del SIDA entre adolescentes (y en particular entre mujeres jóvenes); una mayor consciencia sobre la dinámica social en la definición del comportamiento sexual; y la documentada ineficacia de los programas que se basan sólo en la abstinencia para prevenir embarazos no deseados y relaciones sexuales sin protección. Este número de $Q / C / Q$ informa sobre un país que se comprometió a entregar a todos sus estudiantes un currículum de educación sexual sensible a la problemática del género y basado en la escuela, durante ocho años consecutivos.

A partir de su denominada Revolución Pacífica del 1990, Mongolia ha vivido profundos cambios culturales, entre los que se destaca una mayor precocidad sexual entre los adolescentes y un aumento en los índices de ITS y embarazos no deseados. El gobierno, con el apoyo del FNUAP elaboró un programa nacional, conocido como P0 Zorgaa, que ayuda a los adolescentes a promover su propia salud sexual y reproductiva.

Inicialmente se temía que la educación sexual podría conducir a la promiscuidad, pero al poco tiempo las autoridades quedaron convencidas de que el comportamiento sexual estaba cambiando por cuenta propia, y que la educación podría ayudar a que los jóvenes tomaran decisiones más responsables. Las encuentas con grupos de padres indicaron además que la gran mayoría de éstos querían que sus hijos aprendieran sobre sexualidad, pero que los padres no estaban dispuestos a encargarse del tema.

Un asesor técnico del proyecto organizó un curso de 9 semanas de duración con el fin de crear un Equipo Superior de Capacitación que elaboraría el currículum y luego capacitaría a maestros que lo enseñarían en las escuelas. La capacitación detalló la manera en que las dinámicas sociales-y particularmente el génerodeterminan la toma de decisiones sexuales, el placer sexual, el riesgo de la violencia, y la capacidad de negociar el uso de condones. Por lo dicho, el currículum enfatiza problemáticas sicosociales más que temas técnicos. Los Capacitadores Superiores ya han preparado a más de la mitad de los maestros de la nación.

El proyecto ha enfrentado varios desafíos. El sistema formal de educación dedica apenas 36 horas para la enseñanza sobre sexualidad a lo largo de 8 años. Está claro que para tener un verdadero impacto se necesitan muchas horas más; el personal del proyecto propone como mínimo unas 72 . Otro problema surgió porque tanto las autoridades del gobierno como los miembros del personal del proyecto temían que algunos de los temas pudieran ser controversiales. Por lo dicho, 8 de los temas fueran designados como optativos, aunque siguen siendo parte de la capacitación de maestros y del currículum impreso.

La reacción de los estudiantes ha sido muy positiva. Cuando se les pregunta cuáles temas son los más importantes, los estudiantes señalan aquellos que tienen claras dimensiones de género: la violencia sexual, los embarazos no deseados, las ITS y la toma de decisiones dentro de la relación.

Además del programa escolar, el P0 Zorgaa publica una revista trimestral para adolescentes e imprime un ejemplar por cada 5 adolescentes en el país. Prácticamente la totalidad de los padres y de los políticos han apoyado la revista y el programa de educación sobre sexualidad.

Con el propósito de documentar el impacto, el proyecto ha programado una segunda encuesta de base sobre conocimientos, actitudes y comportamiento. El gobierno también está tratando de complementar el programa en las escuelas con otras actividades.

La experiencia de Mongolia demuestra que: 1) temas como el sexo no deseado y los roles de género preocupan mucho a los adolescentes-y especialmente a las mujeres; 2) el material impreso es un medio de comunicación económico y efectivo; y 3) existen muchos contextos donde los padres no se oponen a la educación sexual, y hasta pueden estar agradecidos por la misma.

Como lo dijo una joven mongola, "Nosotras enfrentamos estos temas todos los días... Tenemos que manejar problemas de amor, relaciones... sexualidad, y necesitamos conocer esta información." 


\section{Résumé en Français}

Avec la propagation du VIH parmi les adolescents (surtout les filles), la conscience croissante du rôle de la dynamique sociale dans la prise de décision en matière sexuelle et l'inefficacité documentée de l'abstinence comme seule méthode de prévention des rapports sexuels non voulus ou sans préservatif, un plus grand nombre de pays cherchent à mettre en œuvre des programmes d'éducation à la sexualité complets. Ce numéro de $Q / C / Q$ offre l'exemple d'un pays qui s'est engagé sur le plan national à fournir à tous les élèves, pendant huit années consécutives, un programme scolaire d'éducation à la sexualité tenant compte de chaque sexe.

Depuis sa révolution pacifique de 1990, la Mongolie a connu des changements culturels spectaculaires, parmi lesquels I'activité sexuelle précoce chez les adolescents, entraînant une augmentation des taux d'IST et de grossesses non voulues. En réponse à cette situation, le gouvernement (avec l'appui du FNUAP) a élaboré un programme national_appelé "P0 Zorgaa" — pour permettre aux adolescents de promouvoir leur propre santé sexuelle et reproductive.

Au début, on redoutait quelque peu que l'éducation à la sexualité n'entraîne la promiscuité. Toutefois, les responsables inquiets ont vite été convaincus du fait que la culture changeait déjà et que l'éducation permettrait aux jeunes de prendre des décisions plus réfléchies. Par ailleurs, des discussions de groupe avec les parents ont clairement montré qu'une majorité écrasante des parents voulaient que leurs enfants soient informés sur la sexualité, mais qu'ils n'étaient pas prêts à dispenser euxmêmes cet enseignement.

Un conseiller technique du projet a organisé un cours de neuf semaines afin de créer une équipe de formateurs principaux qui élaboreraient le programme, puis formeraient les enseignants à son utilisation. La formation a permis de documenter comment la dynamique sociale — surtout la différence entre les sexes-influence fondamentalement la prise de décision en matière sexuelle, le plaisir sexuel, le risque de violence et I'habileté à négocier l'emploi du préservatif. Ainsi, le programme suivant insiste plus sur les questions psychosociales que sur les sujets techniques. Les formateurs principaux ont déjà formé la moitié des enseignants du pays à I'utilisation du programme.

Le projet a été confronté à plusieurs défis. Le programme actuel d'éducation à la sexualité ne comprend que 36 heures s'étalant sur huit ans. Il est évident qu'il faudrait augmenter considérablement ce nombre pour obtenir un véritable impact; le personnel du projet préconise que le nombre d'heures soit au moins doublé. Ensuite, les représentants du gouvernement et le personnel du projet se préoccupaient de ce que certains sujets pourraient être considérés comme délicats. Ainsi, huit sujets ont été désignés comme facultatifs, bien qu'ils soient toujours inclus dans la formation des enseignants et dans le programme publié.

La réaction des élèves a été très positive. Lorsqu'on les interroge sur les sujets les plus importants, ils soulignent ceux portant clairement sur les spécificités de chaque sexe, tels que la violence sexuelle, les grossesses non voulues, les IST et la prise de décision dans les relations.

En plus du programme scolaire, "P0 Zorgaa" publie un journal trimestriel pour adolescents et imprime désormais un exemplaire pour cinq adolescents en Mongolie. Les réactions des politiciens et des parents au journal ainsi qu'à l'enseignement de la sexualité en classe ont été entièrement positives.

Pour documenter cet impact, le personnel du projet refera l'enquête de base sur les connaissances, les attitudes et les comportements. Le gouvernement travaille également afin de compléter le programme scolaire avec d'autres activités.

Parmi les leçons tirées de l'expérience de la Mongolie, on peut retenir les points suivants: 1 ) les questions telles que les rapports sexuels non voulus et les rôles sexuels sont parmi les inquiétudes les plus pressantes des adolescents, surtout des filles; 2) les documents sont un média efficace et peu coûteux; et 3) I'opposition des parents pourrait être pratiquement inexistante dans certains milieux - en effet, lorsque l'occasion leur est donnée, de nombreux parents expriment de la gratitude pour cette éducation.

Comme l'a dit un jeune Mongol, "Nous sommes quotidiennement confrontés à ces sujets... Nous devons nous occuper de questions telles que l'amour, les relations... la sexualité, et il nous faut connaître cette information." 
About the Authors

Delia Barcelona and Laura Laski are Senior Technical Officers, Technical Support Division, UNFPA.

Caitlin Gerdts was formerly an intern with Margaret Sanger Center International in Ulan Bator and in New York City.

Editor: Debbie Rogow

Research and

Production Assistance: Anna Stumpf

Designer: Mike Vosika

\section{Advisory Group}

Errol Alexis

Gary Barker

Judith Bruce

Susana Galdos

Françoise Girard

Nicole Haberland

Judith F. Helzner

Katherine Kurz

Ann Leonard

Ann McCauley

Liz McGrory
Suellen Miller

Isaiah Ndong

Nancy Newton

Saumya Ramarao

Julie Reich

Ann Starrs

Cynthia Steele

Gilberte Vansintejan

Beverly Winikoff

Margot Zimmerman

\section{Acknowledgments}

The author wishes to acknowledge Agi, Bayar, Bold, and Andrea Irvin of the Adolescent Reproductive Health Project (P0 Zorgaa) for extensive help in gathering information for this article and for review of and contributions to the manuscript. Thanks also to Oyun (on leave from the Ministry of Health) and to Linda Demers of UNFPA/Mongolia, both of whom reviewed the text and made helpful suggestions. Finally, the New York staff at Margaret Sanger Center International offered valued collegial support, and both $\mathrm{MSCl}$ and Stanford University generously provided institutional support for different aspects of the development of this article.

We invite your comments and ideas for projects that might be included in future editions of Quality/Calidad/Qualité. If you would like to be included on our mailing list, please send an e-mail to: qcq@popcouncil.org. Most past editions are available online at: www.popcouncil.org/publications. The following are also available in print; single or multiple copies may be ordered by e-mail:

Celebrating Mother and Child on the Fortieth Day: The Sfax Tunisia Postpartum Program (English only), no. 1, 1989.

Man/Hombre/Homme: Meeting Male Reproductive Health Care Needs in Latin America (English, Spanish), no. 2, 1990.

Gente Joven/Young People: A Dialogue on Sexuality with Adolescents in Mexico (English, Spanish), no. 5, 1993.

The Coletivo: A Feminist Sexuality and Health Collective in Brazil (English, Portuguese), no. 6, 1995.

Doing More with Less: The Marie Stopes Clinics of Sierra Leone (English only), no. 7, 1995.
Introducing Sexuality within Family Planning: Three Positive Experiences from Latin America and the Caribbean (English, Spanish), no. 8, 1997.

Using COPE to Improve Quality of Care: The Experience of the Family Planning Association of Kenya (English, Spanish), no. 9, 1998.

Alone You Are Nobody, Together We Float: The Manuela Ramos Movement (English, Spanish), no. 10, 2000.

From Patna to Paris: Providing Safe and Humane Abortion (English only), no. 11, 2001. 